\title{
New hypogean cyclopoid copepods (Crustacea) from the Yucatán Peninsula, Mexico
}

\author{
Frank Fiers ${ }^{1}$, Janet W. Reid ${ }^{2}$, Thomas M. Iliffe ${ }^{3} \&$ Eduardo Suárez-Morales ${ }^{4}$ \\ ${ }^{1}$ Invertebrate Section, Royal Belgian Institute of Natural Sciences, Vautierstraat 29, B-1000 Brussels, Bel- \\ gium; ${ }^{2}$ Department of Invertebrate Zoology, MRC-163, National Museum of Natural History, Smithsonian \\ Institution, Washington DC 20560, U.S.A.; ${ }^{3}$ Department of Marine Biology, Texas A\&M University, \\ Galveston, Texas 77553-1675, U.S.A.; ${ }^{4}$ ECOSUR, El Colegio de la Frontera Sur - Unidad Chetumal, Apdo \\ Postal 424, Chetumal, Q. Roo 77000, Mexico
}

Keywords: Diacyclops, Mesocyclops, Copepoda, Cyclopoida, biogeography, evolution, hypogean, karst, species-flock, taxonomy, Mexico

\begin{abstract}
Four previously unknown hypogean species of cyclopoid copepods were collected in cenotes and wells of the Yucatán Peninsula, Mexico. Diacyclops chakan sp. n. and D. puuc sp. n. differ from their congeners in combining 3-segmented swimming legs, 11-segmented antennules, and legs 1-4 endopodite segment 2 all with 2 setae. Species of Diacyclops rarely occur in tropical regions, and the Diacyclops described here are only the second and third species recorded from Mexico. The benthic $D$. puuc was found in the large underground reservoir of a cenote. Diacyclops chakan was encountered in such large open subterranean water basins, but more frequently and abundantly in wells.

The two Mesocyclops species, $M$. chaci sp. n. and M. yutsil sp. $n$., most closely resemble their epigean benthic congener $M$. reidae Petkovski, but are modified by loss of some body ornament and attenuation of swimming legs and mouthparts. Mesocyclops chaci sp. n. occupies crevicular spaces (wells and small caverns). The second species, $M$. yutsil sp. n., with more pronounced attenuation of legs, has a planktonic life in large subterranean water volumes. The extremely attenuated appendages of both species distinguish them from all other Mesocyclops, and resemble those of the hypogean Kieferiella delamarei Lescher-Moutoué. These three species are considered as a species-flock which have radiated as specialists within a highly dynamic geomorphological environment.
\end{abstract}

\section{Resumen}

Se recolectaron, en cenotes y pozos de la Peninsula Yucatán, México, cuatro especies de copépodos ciclopoides hipógeos previamente desconocidos. Diacyclops chakan sp. n. y D. puuc sp. $n$. difieren de sus congéneres al combinar patas natatorias trisegmentadas, anténulas de 11 segmentos y 2 setas en el segundo segmento del endopodito de las patas $1-4$. Las especies del género Diacyclops ocurren raramente en las regiones tropicales y los dos Diacyclops aquí descritos son el segundo y tercer representantes del género registrados en México. La especie béntica $D$. puuc se ha encontrado en un grande cuerpo de agua subterránea (cenote). Diacyclops chakan se ha encontrado sólo excepcionalmente en estes cuerpos grandes de aguas subterráneas, pero es frecuente y abundante en pozos.

Las dos especies de Mesocyclops, $M$. chaci sp. n. y $M$. yutsil sp. n. son muy semejantes a la especie béntica $M$. reidae Petkovski, pero están modificadas para la vida hipógea con la pérdida parcial de omamentaciones en el cuerpo y el adelgazamiento de las patas natatorias y partes bucales. Mesocyclops chaci sp. n. vive in lugares creviculares como las paredes de pozos y cavernas pequeñas. Mesocyclops yutsil sp. n. se caracteriza por el más pronunciado adelgazamiento de las patas, es planctónica y vive en cuerpos grandes de aguas subterráneas. Los apéndices extremadamente adelgazados distinguen las dos especies de los demás Mesocyclops y son similares a los de la especie hipógea Kieferiella delamarei Lescher-Moutoué. Las tres especies de Mesocyclops son consideradas como un particular conjunto que ha radiado como especialistas dentro de un ambiente geomorfológico altamente dinámico.

\section{Introduction}

Collections of crustaceans from cenotes, wells and caves in the States of Yucatán and Quintana Roo, Mexico, contained four previously unknown cyclopine copepods, two Diacyclops and two Mesocyclops. These are described and their possible systematic affinities discussed by F. Fiers and J.W. Reid. We describe the geological and ecological conditions that might have contributed to the evolution of these hypogean species. 


\section{Methods}

Some specimens, collected by T.M. Iliffe and colleagues, were taken with a plankton net from the surface to as deep as $30 \mathrm{~m}$ in several cenotes. Although the water in most cenotes was "fresh" $\left(0-2 \%_{0}\right)$ at those depths, most samples contained copepods of both continental freshwater and marine affinities. The latter were sent to appropriate specialists for determination and description.

Crustaceans collected by F. Fiers and colleagues came from a wide variety of habitats, including man-made wells, open cenotes and nearly closed aguadas (karstic caverns with a small to large water pool). All samples were taken with a plankton net that was repeatedly lowered in the water column and rapidly withdrawn to create a current sweeping the walls of the water reservoirs.

In the same way, Dr. F. Moravec and his assistants collected Mesocyclops chaci sp. $\mathrm{n}$. in a closed man-made well near Cheuman, Yucatán, and used this species succesfully as the experimental intermediate host of two nematode species parasitic in fish (F. Moravec, in litt. to F. Fiers).

Specimens were fixed in formalin and transferred to $70-75 \%$ ethanol for long-term storage. For taxonomic examination, they were transferred in stages to glycerine and examined either in glycerine (J.W. Reid and F. Fiers) or in lactic acid (J.W. Reid). Permanent mounts were made in polyvinyl lactophenol (PVL) with a little chlorazol black E added (J.W. Reid) or in glycerine with sealed coverglasses (F. Fiers). J.W. Reid made most drawings at magnifications of $600 \times$ and confirmed the details at $1000 \times$ using an oil immersion lens on a Wild M30 microscope fitted with a drawing tube. F. Fiers made his drawings at $1250 \times$ using an oil immersion lens on a Leitz Dialux 20, equipped with a drawing tube. Undissected specimens were preserved in $70 \%$ ethanol.

The specimens were deposited in the collections of the Department of Invertebrate Zoology, United States National Museum of Natural History, Smithsonian Institution (USNM) and in the Invertebrate Collection of the Royal Belgian Institute of Natural Sciences, Brussels (COP).

\section{Descriptive part}

Family Cyclopidae Burmeister, 1834

Subfamily Cyclopinae Dana, 1853, emend. Kiefer, 1927

Genus Diacyclops Kiefer, 1927

\section{Diacyclops chakan Fiers \& Reid, sp. n.}

(Figs. 1-7)

Synonymy. - Diacyclops sp. A, Suárez-Morales et al., 1996: 124, figs. 27-30. - ?Mesocyclops leuckarti Claus, 1857, of Wilson, 1936: 82, 85-88 (partim); Pearse \& Wilson, 1938: 153 (partim).
Type-specifications. - Holotype, dissected 9 , mounted on 3 slides, labeled COP 3863a, b, c; allotype $\sigma$, dissected, mounted on 3 slides, COP $3864 \mathrm{a}, \mathrm{b}$, c; dissected paratypes: 1 \&, COP 3865a, b, c; 1 \&, COP 3866a; $1 \sigma^{\circ}$, COP 3867a, b, c; ethanolpreserved paratypes: $69 \%$, $1 \sigma^{\circ}$, COP 3868, and sample filtrate (still containing many specimens), COP 3920; 24 \& , $1 \%, 5$ copepodids, USNM 274313.

Type-locality: man-made well (pozo), located on property of "Rancho Antonio Kanah" along Kinchil - Celestún road (Yucatán), approximately $23 \mathrm{~km}$ from Kinchil, and $1 \mathrm{~km}$ from road. Coordinates (estimated): $20^{\circ} 53^{\prime} 30^{\prime \prime} \mathrm{N}, 9^{\circ} 07^{\prime} 09^{\prime \prime} \mathrm{W}$. Well has diameter of $1 \mathrm{~m}$, depth $4 \mathrm{~m}$. Bottom sediments are fine brilliant white sand. At time of sampling, well contained $1 \mathrm{~m}$ of water, and was covered with iron lid. Sample MEX 93-88, leg. J. Vargas, M. Herrera, and F. Fiers, 8 November 1993. - Additional copepod fauna: 1 \& copepodid stage V Macrocyclops albidus (Jurine, 1820) s. str., COP 3869a, b, c; and crustacean fauna: Antromysis cenotensis (Creaser, 1936), Typhlatya pearsei Creaser, 1936; ostracodes; 1 stygobiotic amphipod.

Additional material. -

(1) Chen-Ha Cenote, Chochola (Yucatán), west side of main highway midway between Chochola and Maxcanu. Coordinates: $20^{\circ} 34^{\prime} 10^{\prime \prime} \mathrm{N}, 8^{\circ} 52^{\prime} 30^{\prime \prime} \mathrm{W}$. Commercially operated freshwater swimming cenote consisting of open pool $95 \mathrm{~m}$ long by $64 \mathrm{~m}$ wide, with large underwater cavern entrance extending $25 \mathrm{~m}$ horizontally; maximum depth in open pool $24 \mathrm{~m}$, in cavern $30 \mathrm{~m}$; bottom primarily mud. Sample taken with $93 \mu \mathrm{m}$ mesh plankton net at 18-28 m depths in cavern. Sample 93-043, leg. T.M. Iliffe, 6 July 1993: 1 \&, dissected on slide in PVL, USNM 259839. - Additional copepod fauna: Mastigodiaptomus albuquerquensis (Herrick, 1895), 1 ९, 4 copepodids, USNM 278028; Macrocyclops albidus s. str., 1 ơ, USNM 278030; Microcyclops sp., 1 copepodid, USNM 278029; Thermocyclops inversus Kiefer, 1936, $11 \% \propto$ and $\sigma^{\circ} \circ$, USNM 278031; and crustacean fauna: amphipods, thermosbaenaceans.

(2) Mucuyché Cenote, located within the ruins of a hacienda in the village of Mucuyché (Yucatán). Coordinates: $20^{\circ} 37^{\prime} 23^{\prime \prime} \mathrm{N}$, $89^{\circ} 36^{\prime} 18^{\prime \prime} \mathrm{W}$. From the crescentic sinkhole entrance, a flight of steps leads down a breakdown slope to a $30 \mathrm{~m}$ long by $10 \mathrm{~m}$ wide, gravel and rock floored freshwater pool. On the far side of the pool at about $8 \mathrm{~m}$ water depth, a narrow hole opens onto a $50 \mathrm{~m}$ long, $10 \mathrm{~m}$ wide breakdown chamber that angles diagonally down to $30 \mathrm{~m}$ depth. At this point, a vertical breakdown shaft ascends to $15 \mathrm{~m}$ depth before choking off. Sample taken with plankton net at $20-30 \mathrm{~m}$ depth in breakdown chamber. Sample 93-045, leg. T.M. Iliffe, 9 July 1993: 1 ơ, USNM 259840, 1 copepodid, USNM 259842. - Other crustacean fauna: mysids (Antromysis cenotensis), thermosbaenaceans, amphipods, and isopods [Creaseriella anops (Creaser, 1936)]. (3) Yuncu Cenote, located $1.5 \mathrm{~km}$ west of Yuncu (Yucatán), on east side of abandoned railroad right-of-way running north to south. Coordinates: $20^{\circ} 34^{\prime} 51^{\prime \prime} \mathrm{N}, 8^{\circ} 36^{\prime} 46^{\prime \prime} \mathrm{W}$. Vertical pit entrance, $7 \mathrm{~m}$ diameter and $10 \mathrm{~m}$ deep; a freshwater, U-shaped pool extends $3 / 4$ of the way around the northern side of the $40 \mathrm{~m}$ long by $37 \mathrm{~m}$ wide entrance chamber. The pool on the east side of the chamber averages about $1 \mathrm{~m}$ deep, but on the west side 
the pool extends down to over $30 \mathrm{~m}$ deep where it pinches out between breakdown and the bedrock wall. Sample taken with plankton net at 15-30 m depths. Sample 93-046, leg. T.M. Iliffe, 10 July 1993: 1 \%, USNM 259841. - Additional copepod fauna: subspecies of Tropocyclops prasinus (Fischer, 1860) s. 1., 5 \& \& , 2 ○ ơ, USNM 278027; Mesocyclops yutsil sp. n., see below. Other crustacean fauna: mysids (Antromysis cenotensis), ostracodes, thermosbaenaceans, amphipods, and isopods.

(4) Pozo (well) near Presumida (Quintana Roo), $1.5 \mathrm{~km}$ from La Presumida (7.5 km southeast of Morelos) on road to Chetumal; $80 \mathrm{~cm}$ diameter, $6 \mathrm{~m}$ deep man-made well containing $1.5 \mathrm{~m}$ of water; about $2 \mathrm{~km}$ at the right side from the main road. Estimated coordinates $19^{\circ} 46.250^{\prime} \mathrm{N}, 88^{\circ} 45.704^{\prime} \mathrm{W}$. Sample Mex 94-008, leg. J. Vargas, V. Ceja, and F. Fiers, 12 April 1994: 1 dissected \&, COP 3870a, b, c; 13 \& ९, 3 \% \% , COP 3871. Additional copepod fauna: Mesocyclops reidae Petkovski, 1986: 1 \&, dissected, COP 3872a, b, c, 16 \%, 2 copepodids, COP 3873; and crustacean fauna: Antromysis cenotensis, stygobiotic amphipods.

(5) Aguada (Quintana Roo): cavern located $3 \mathrm{~km}$ left of Morelos-Chetumal road, small water reservoir, $4 \mathrm{~m}$ long, $2 \mathrm{~m}$ in diameter, deepening to $1.10 \mathrm{~m}$ at extreme end of cavern; domestic use; bottom covered with fine organic material; salinity $0 \%$. Estimated coordinates $19^{\circ} 51^{\prime} 00^{\prime \prime} \mathrm{N}, 88^{\circ} 35^{\prime} 11^{\prime \prime} \mathrm{W}$. Sample Mex 94-009, leg. J. Vargas, V. Ceja, and F. Fiers, 12 April 1994: 9 \& $\$, 3$ copepodids, COP 3874. - Additional copepod fauna: Mesocyclops reidae: 2 ९ , COP 3874; Paracyclops chiltoni (Thomson, 1882), COP 4090; and crustacean fauna: Antromysis cenotensis, Creaseria morleyi (Creaser, 1836), Tulumella sp.

(6) Pozo (well) 1 at San Domingo (Quintana Roo), on left side of Morelos-Chetumal road; first village east of Lago Esmeralda, on dirt road to La Esperanza; man-made well on right side of road through village, uncovered, domestic use, $14 \mathrm{~m}$ deep, $1 \mathrm{~m}$ diameter, containing $1 \mathrm{~m}$ of water. Estimated coordinates $19^{\circ} 46.436^{\prime} \mathrm{N}, 88^{\circ} 42.721^{\prime} \mathrm{W}$. Sample Mex 94-011, leg. J. Vargas, V. Ceja, and F. Fiers, 12 April 1994: 1 \& , 5 copepodids, COP 3876. - Additional copepod fauna: Mesocyclops reidae: 1 dissected \&, COP 3871a, b, c, 1 \%, COP 3870; calanoids; and crustacean fauna: Antromysis cenotensis, Typhlatya cf. pearsei. (7) Pozo 2 at San Domingo (Quintana Roo), same village as in nr. (6) but on left side of dirt road, situated $\pm 4 \mathrm{~m}$ higher than previous locality; man-made well, $16 \mathrm{~m}$ deep, $1.20 \mathrm{~m}$ diameter, containing about $2 \mathrm{~m}$ of water, uncovered, domestic use. Estimated coordinates $19^{\circ} 47.501^{\prime} \mathrm{N}, 88^{\circ} 42.721^{\prime} \mathrm{W}$. Sample Mex 94-012, leg. J. Vargas, V. Ceja, and F. Fiers, 12 April 1994: 12 \& 9,64 copepodids, COP 3877. - Additional copepod fauna: Eucyclops cf. conrowae Reid, 1992, COP 3862; and crustacean fauna: ostracodes, stygobiotic amphipods.

(8) Pozo "Ticuch", $500 \mathrm{~m}$ left, $1 \mathrm{~km}$ out of Ticuch Village (Yucatán) on road to Valladolid, $20^{\circ} 41.786{ }^{\prime} \mathrm{N}, 88^{\circ} 08.189^{\prime} \mathrm{W}$. Man-made well, $1 \mathrm{~m}$ diameter, $36.5 \mathrm{~m}$ deep, containing $1.5 \mathrm{~m}$ water. Sample Mex 94-015, leg. J. Vargas and M. Herrera, 18 April 1994: 100+ $\% ~ \&, \sigma^{\circ} \sigma^{\circ}$, and copepodids, COP 3881; 1 dissected $\$$, COP $3880 \mathrm{a}, \mathrm{b}, \mathrm{c}$. - Additional crustacean fauna: none.

(9) Pozo "Temozon" in Temozon Village (Yucatán), man-made well, $1 \mathrm{~m}$ diameter, $35 \mathrm{~m}$ deep, with $1.5 \mathrm{~m}$ of water. Coordinates $20^{\circ} 48.216^{\prime} \mathrm{N}, 88^{\circ} 11.895^{\prime}$ W. Sample Mex 94-019, leg. J. Vargas and M. Herrera, 18 April 1994: 30 \% \&, $2 \sigma^{\circ} \sigma^{\circ}$, and 4 copepodids, COP 3883; 1 \%, dissected, COP 3882a, b, c. Additional copepod fauna: calanoids; and crustacean fauna: Antromysis cenotensis, Typhlatya cf. pearsei.

(10) Yuncu Cenote, Yuncu (Yucatán), depth 0-5 m, sample 94-023, 13 August 1994, leg. T.M. Iliffe: 7 \% , 1 \%, 4 copepodids, USNM 271850. - Additional copepod fauna: Mastigodiaptomus nesus (Bowman, 1986), 1 \%, USNM 271855; Macrocyclops albidus s. str., 1 ơ, USNM 271853; Mesocyclops yutsil sp. n., USNM 271864; Paracyclops chiltoni, $10^{\circ}$, USNM 271862; subspecies of Tropocyclops prasinus s. 1., 200+, USNM 271865; marine cyclopoids.

(11) Ponderosa Cenote, Puerto Aventuras (Quintana Roo), part of $11.5 \mathrm{~km}$ long cave system located $4 \mathrm{~km}$ south of Puerto Aventuras and $1 \mathrm{~km}$ inland (west) from main coastal highway. Coordinates: $20^{\circ} 31 \mathrm{~N}, 87^{\circ} 14^{\prime} \mathrm{W}$. Large cavern extends back $90 \mathrm{~m}$ to the Corral Cenote; from this an underwater passage extends over $600 \mathrm{~m}$ to a partly air-filled chamber called the Chapel. Halocline at $11.5 \mathrm{~m}$. Sample taken with plankton net from water column at or below halocline in passage to Chapel at 10-16 m depths. Sample 95-020, leg. T.M. Iliffe, 25 July 1995 : 1 \&, 2 copepodids, 1 nauplius (poor condition, dead when caught), USNM 264231. - Additional copepod fauna: harpacticoids.

Description of female. - Length of holotype 676 $\mu \mathrm{m}$; lengths of 5 paratypes ranging from 551 to 727 $\mu \mathrm{m}$, mean $=679 \mu \mathrm{m}$ (Chen Ha specimen $570 \mu \mathrm{m}$, Yuncu specimen $560 \mu \mathrm{m}$ : specimens telescoped). Habitus (Fig. 1a) slender in dorsal view, with posterolateral margins of pedigerous somites 3,4 and 5 produced posteriorly (less produced in Yuncu specimens), without surface ornament except for dorsal sensilla (latter not illustrated); genital double somite widest in anterior half $(152 \mu \mathrm{m})$, tapering posteriorly (Fig. 2a, b); about as long as wide (ratio length/width $1: 0.94$ ); ratio urosome/ body length: $1: 2.89$. Hyaline fringes of urosomites weakly crenulate dorsally and ventrally; anal somite ornamented with small spinules along posterior margin; surface naked except for paired dorsal sensilla; anal operculum wide, weakly crescentic; anal sinus smooth.

Caudal ramus (Fig. 2c, d) 2.5 (in holotype, ranging from 2.29 to 2.64 in paratypes) times longer than wide with large indented triangular area in anterior half of medial margin; surface smooth except for few small spinules on anterior third of outer margin, and near implantation of lateral and lateralmost terminal setae; apical ventral margin some- 


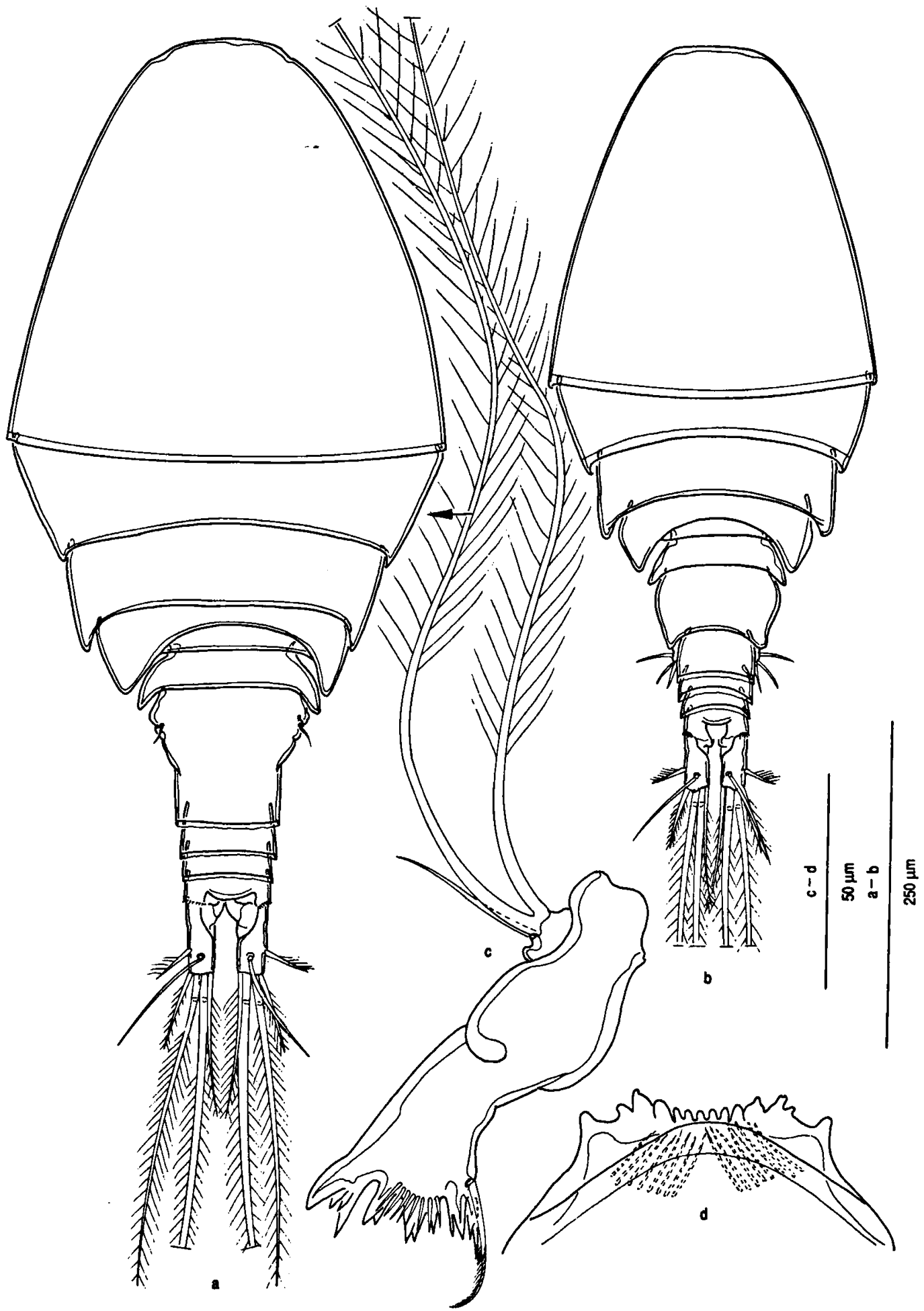

Fig. 1. Diacyclops chakan sp. n., a, c-d, holotype $९$, COP 3863; b, allotype ơ, COP 3864: a, habitus, dorsal (arrow indicates maximum length of antennule); b, habitus, dorsal; $c$, mandible; $d$, labrum. 


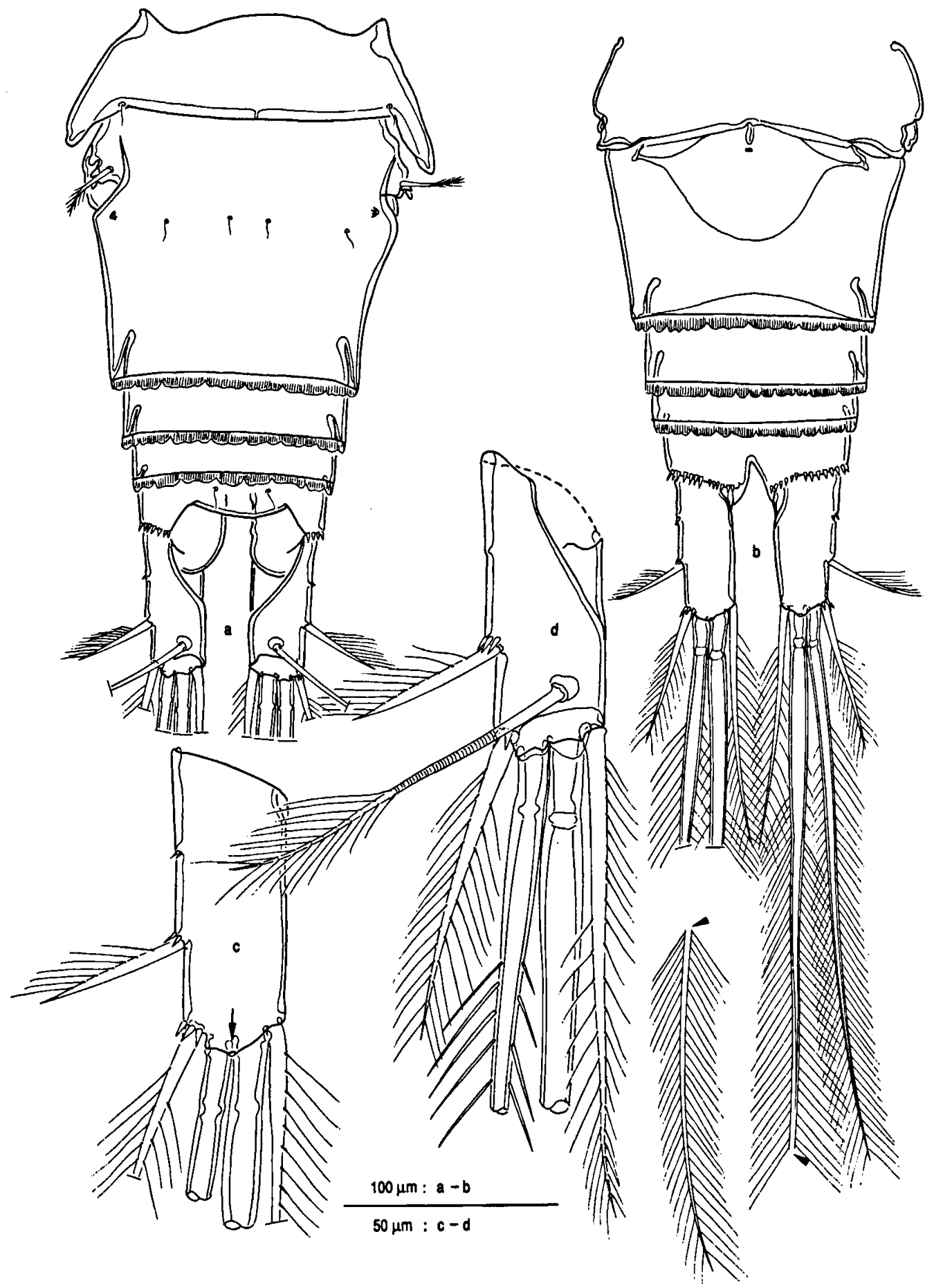

Fig. 2. Diacyclops chakan sp. n., paratype \&, COP 3865: a, abdomen, dorsal; b, abdomen, ventral; c, caudal ramus, ventral; d, caudal ramus, dorsal. 


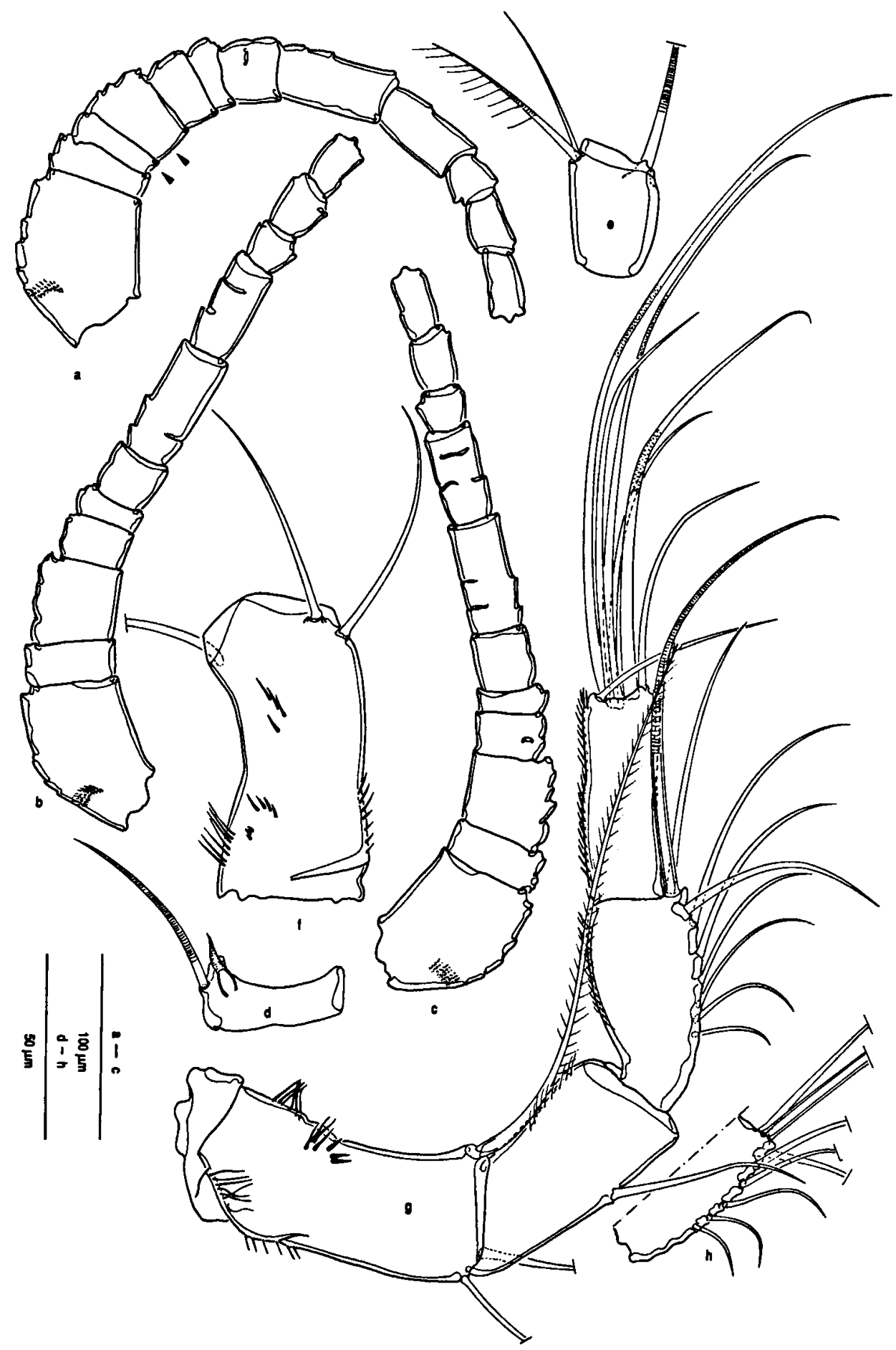

Fig. 3. Diacyclops chakan sp. n., a, g, holotype \&, COP 3863; b-e, paratype ९, COP 3866; f, paratype ९, COP 3865; h, allotype ơ, COP 3864: a, anomalous antennule; $b$, antennule; $c$, antennule; d, antennular segment $V ; e$, antennular segment $X$; $f$, basipodite of antenna, caudal view; $g$, antenna, frontal view; $h$, appendages of second endopodal segment of antenna. 
what produced, with pore orifice at tip (arrow: Fig. $2 \mathrm{c})$; lateral seta $(30 \mu \mathrm{m}$, Chen Ha spec. $25 \mu \mathrm{m}$, Yuncu spec. $26 \mu \mathrm{m}$, mean $=28.5 \mu \mathrm{m}$ ) arising at base of posterior third of outer margin, rather robust in appearance, plumose along anterior side of stem; lateralmost terminal seta plumose, 1.2 times as long as ramus; dorsal seta $(91 \mu \mathrm{m}$; Chen $\mathrm{Ha}$ spec. 90 , Yuncu spec. $95 \mu \mathrm{m}$ ) with minute basal articulation, inserted at $8 / 10$ length of ramus, slightly medially to dorsal midline, distal half plumose; lengths of lateralmost to medialmost terminal setae: 56, 209, 333, and $95 \mu \mathrm{m}$ (Chen Ha spec.: $38,157,276,73$, Yuncu spec.: 58,200 , broken, 98). Median terminal setae slightly swollen in proximal fourth, and plumose; medialmost seta 1.85 times longer than ramus.

Seminal receptacle (Fig. 2b) with anterior part little produced and nearly absent; posterior part broad, rounded, reaching posterior third of genital double somite; lateral arms narrow and pore canal straight.

Antennule (Fig. 3a-e) normally 11-segmented (paratypes, Chen $\mathrm{Ha}$ and Yuncu material) and reaching middle of second thoracic somite (Fig. 1a: arrow); surface of segments smooth, except for short comb of spinules on segment I. Segments (Roman numerals) with number of setae (Arabic numerals), spines and aesthetascs in parentheses: I (8), II (4), III (8), IV (3), V (1+spine), VI (2), VII (3), VIII (2+aesth.), IX (2), X (3), XI (7+aesth.). Spine on segment $\mathrm{V}$ with thick basis and striated tip (Fig. 3d). Aesthetasc on segment VIII reaching midlength of segment. Slender naked seta on segment X may represent aesthetasc (Fig. 3e). Segmentation variable: Chen $\mathrm{Ha}$ specimen with partially divided segment III; holotype specimen with segment III entirely divided, forming 12-segmented antennule; paratypes (COP 3866) with remnants of articulations in segments VII and VIII. No hyaline membrane on distalmost segments (left antennule of holotype female, COP 3863, broken in two parts).

Antenna (Fig. 3f-h) of 4 segments, bearing 2 abexopodal setae and 1 long finely feathered exopodal seta on basipodite; second segment with 1 , third (second endopodal) segment with 9 and terminal segment with 7 slender setae. Chen Ha specimen with 7 and 8 setae on second endopodal seg- ment. Caudal surface of basipodite (Fig. 3f) with proximal group of long slender spinules along outer and abexopodal margins, and 2 short rows of spinules on surface ( 3 minute ones, 4 longer ones; only 2 long ones in Chen Ha specimen); distal half with irregular row of 4 slender spinules, 5 in Chen Ha specimens. Frontal side of basipodite (Fig. 3g) furnished with row of hair-like spinules along proximal abexopodal margin, and crescentic row of 7 slender spinules near midlength of exopodal margin (4 spinules in Chen Ha specimen).

Labrum (Fig. 1d) with 12 blunt central teeth between produced rounded lateral corners, and 2 rows of long hairs on frontal surface. Cutting edge concave.

Mandible (Fig. 1c) with complex biting edge formed by sharp teeth and 1 seta. Innermost dorsal surface with row of spinules parallel to biting edge. Mandibular palp small but distinct, bearing normal armament: 2 long, finely plumed setae $(278 \mu \mathrm{m})$ and 1 short smooth seta $(39 \mu \mathrm{m})$.

Arthrite of maxillule (Fig. 4d) with 11 appendages: innermost ones strong, hookshaped, and jointed with a long curved one, partially furnished with long setules along one side of stem. Next outermost seta large and rigid, distinctly constricted in middle and plumose in distal half. Maxillular palp with normal armament of 3 endopodal, 1 exopodal and 3 medial setae. Yuncu specimens with arthrital appendages all ornamented with setules.

Maxilla (Fig. 4a) with normal morphology and setation, claw armed with very fine teeth on middle half of concave border and short group of teeth in middle of convex border. Endopodite ornamented with 3 rigid setae, plumose on proximal third but pinnate on middle and distal third, 1 slender plumed seta and 1 short naked seta.

Maxilliped (Fig. 4e) with normal appearance, armed with long setae ornamented with broadly spaced rigid plumes, except for 2 smooth apical setae and spinulose distal half of one seta on penultimate and one on terminal segments. Surface of segment 1 smooth, but with 2 combs of spinules in Chen Ha specimen; of segment 2 with 3 crescentic posterior combs and 1 frontal comb; of segment 3 with series of frontal spinules, and of segment 4 smooth.

Legs 1-4 (Figs. 5a-d, 6a-e) with 3-segmented 


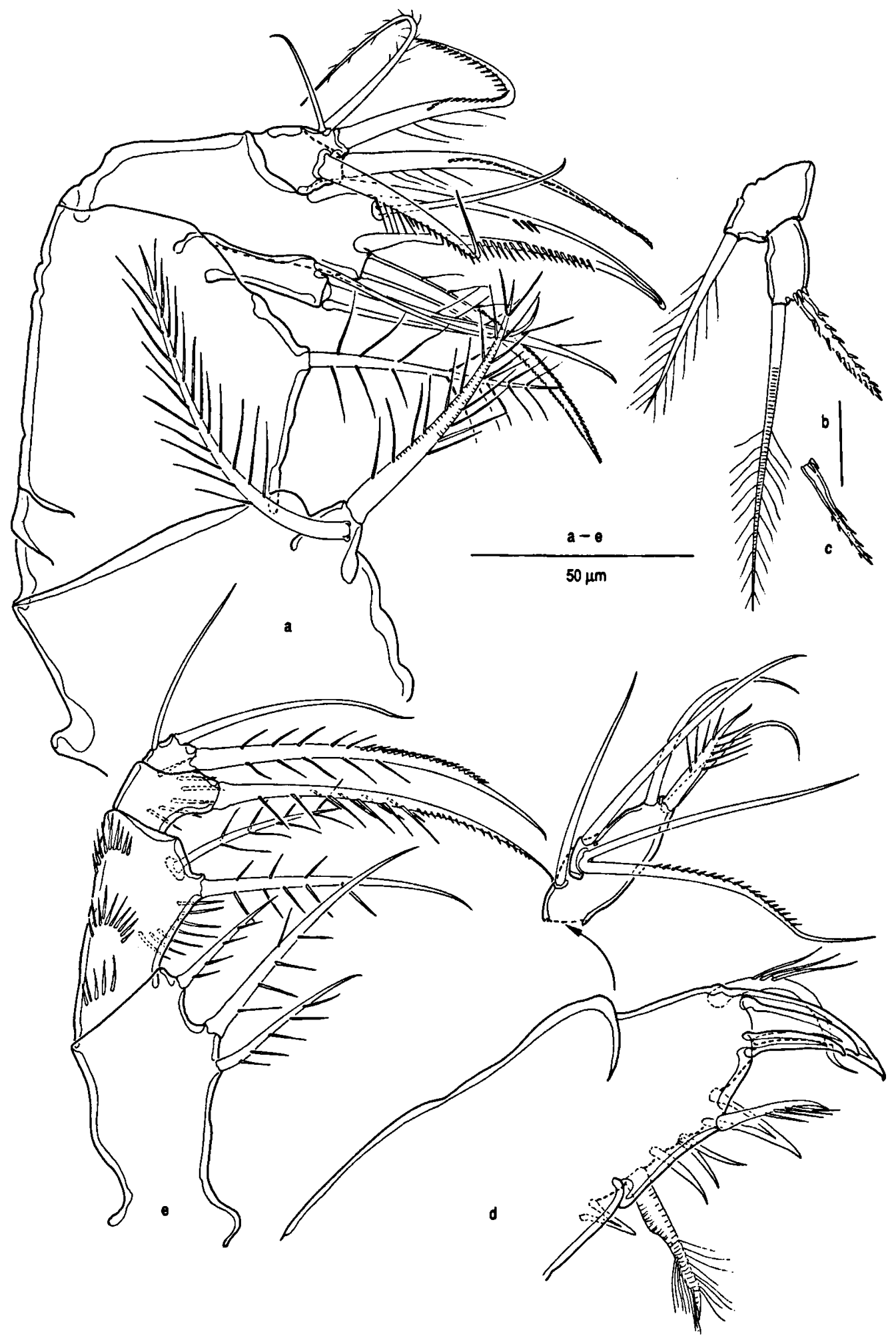

Fig. 4. Diacyclops chakan sp. n., a, c-e, holotype $९$, COP 3863; b, paratype $९$, COP 3865: a, maxilla; b, leg 5; c, leg 5 medial spine; d, maxillule; e, maxilliped. 


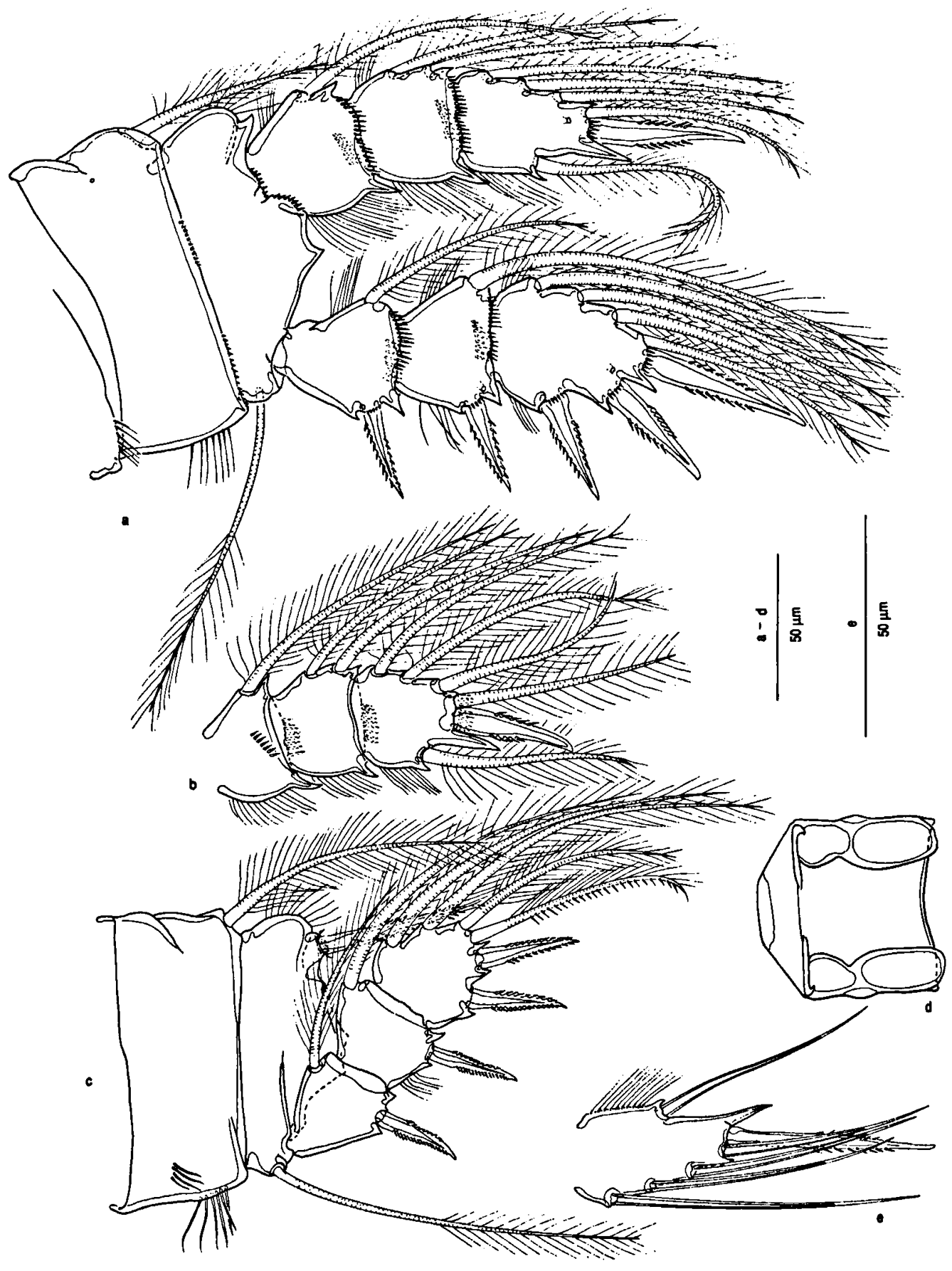

Fig. 5. Diacyclops chakan sp. n., a-d, holotype \&, COP 3863; e, allotype ơ, COP 3864: a, leg 2, anterior; b, leg 1 endopodite, posterior; c, leg 1 protopodite and exopodite, posterior; d, leg 3 coupler, anterior; e, third endopodal segment of leg 2 of male, posterior. 


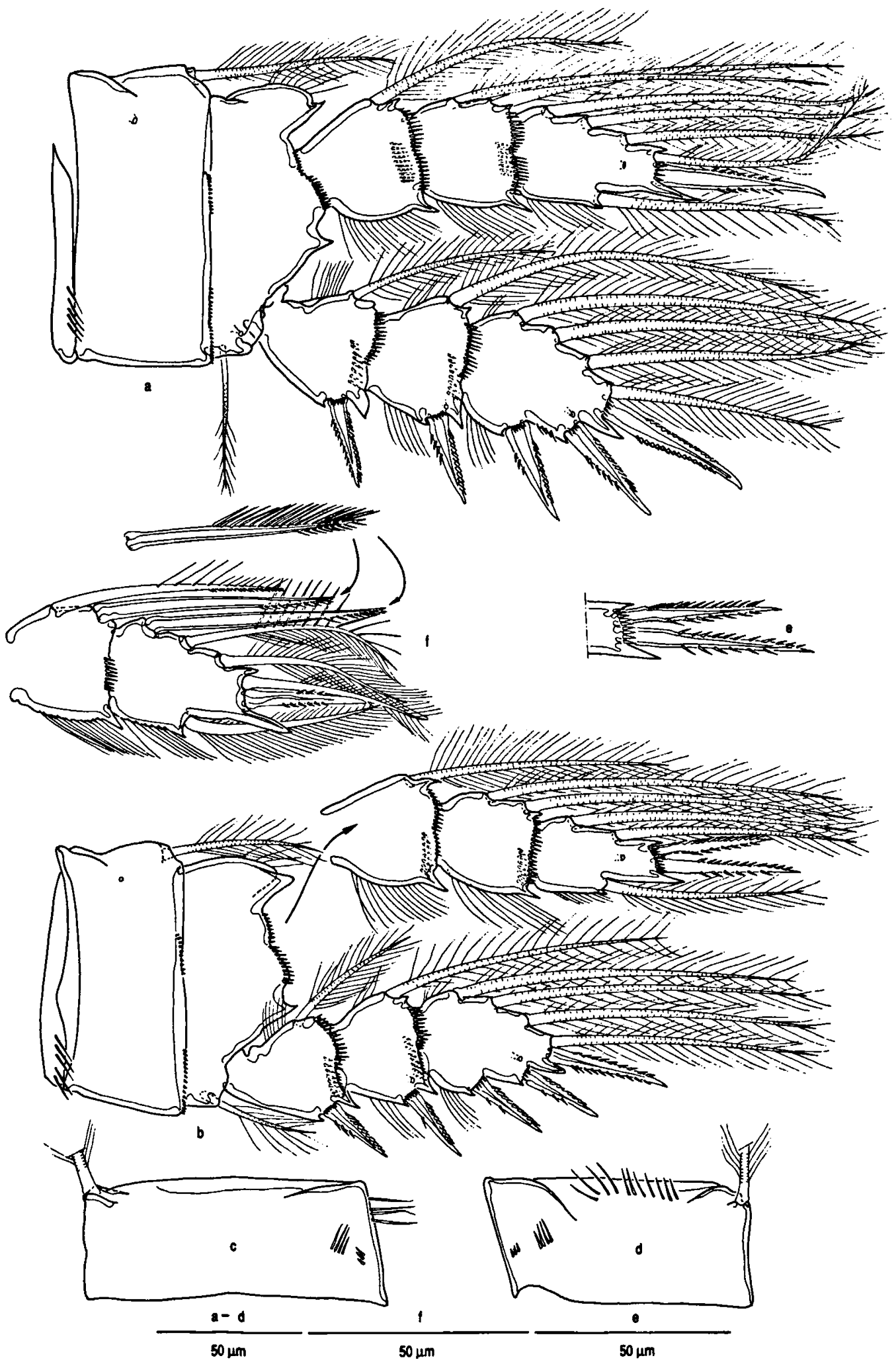


rami. Praecoxa with short row of setules near outer border. Coxopodite of leg 1 ornamented with long slender setules along outer border and on posterior surface (Fig. 5c); anterior surface with 2 small combs of spinules near outer margin (Fig. 6c). Coxopodite of legs 2-4 each with smooth anterior surface, except for 2 rows of minute spinules along distal border. Posterior surface of leg 4 coxopodite (Fig. 6d) with 2 combs of spinules near outer border, and transverse row of long spinules along distal border. Couplers of all legs smooth. Leg 1 basis with medial spine reaching slightly beyond second endopodite segment; median margin and medial corner rounded. Basis of legs 2-4 with spinule row near articulation with endopodite; median and medial distal edges produced. Terminal segments of legs 1-4 exopodites with 2, 3, 3, 3 spines and 4, 4, 4, 4 setae, respectively. Exopodal spines of legs 1 and 4 slender, of legs 2 and 3 relatively stout; exopodal spines of leg 1 slightly extended in slender hairlike tips. Ornamentation of exopodal spines of legs 2-4 and outer distal spine on terminal endopodal segment of legs 1-3 located in median part of stem (length of ornamentation variable), distal part of spines smooth and blunt. Leg 4 terminal endopodal segment 2 times as long as wide in holotype (1.7-1.9 in Yuncu specimens); with 2 distal spines: medial spine as long as segment, outer spine 1.2 times as long as segment; medial spine slightly "sprung" medially, with slender tip.

Leg 5 (Fig. 4b, c) typical for genus, with broad basal segment and subterminally implanted medial spine on exopodite. Exopodite about 1.5 times as long as wide, furnished with some minute spines near insertion of medial spine. Medial spine irregularly armed along inner and outer margin. Spine/ seta ratio: 3.8 ; spine/exopodite ratio: 1.66. Holotype and some paratype specimens with straight medial spine, Chen $\mathrm{Ha}$ and other paratypes with more curved spine (Fig. 4c).

Leg 6 (Fig. 2a) with 1 medial seta ( $30 \mu \mathrm{m}$ long) and 2 blunt outer elements, outermost slightly longer than median one.
Egg sacs containing 2 relatively large eggs (observed in only 2 paratype specimens).

Description of male. - Length: $544 \mu \mathrm{m}(500 \mu \mathrm{m}$ in Mucuyché specimen), with same appearance as female (Fig. 1b). Greatest width of sixth thoracic somite $126 \mu \mathrm{m}$, length/width ratio: $0.66: 1$.

Caudal rami (Fig. 7a) slightly shorter than in female. Length/width ratio: $2: 1$. General appearance of caudal setae as in female.

Antennule (Fig. 7b) geniculate, with 16 segments; terminal segment extended in blunt transparent process.

Leg 2 endopodite terminal segment (Fig. 5e) with outer terminal spine 1.3 times as long as segment. Inner setae on middle and terminal segments of leg 3 endopodite (Fig. 6f) distinctly different from female: distal seta on middle and proximal seta on terminal segment distinctly more robust, ornamented with long spinules along most of medial side of stem and short spinules on distal third of outer side of stem; median inner seta on terminal segment with long spiniform setules along medial side of stem, plumose along lateral face. Leg 4 endopodite segment 3, 2.5 times as long as wide in allotype, ranging from 2.4 (paratype) to 2.7 (Mucuyché specimen). Proportional lengths of terminal spines on endopodite segment 3 as in female.

Leg 5 (Fig. 7a) as in female but with seta/spine ratio of only $2.1: 1$, and spine/exopodite ratio: $1.28: 1$.

Surface of leg 6 with transverse row of spinules. Outer margin furnished with 1 plumose seta, 1 smooth spine, and 1 armed spine.

Etymology. - The species is named chakan, which in Mayan refers to feathers, because of the long setae of the caudal ramus and the swimming legs; proposed in apposition.

Discussion and comparisons. - Diacyclops chakan is discussed together with $D$. puuc sp. n.

Fig. 6. Diacyclops chakan sp. n., a-b, e, holotype \&, COP 3863; c-d, paratype \&, COP 3864; f, allotype ơ, COP 3864: a, leg 3, anterior; b, leg 4, anterior; c, leg 1 coxopodite, anterior; $d$, leg 4 coxopodite, posterior; e, terminal spines of leg 4 endopodite; f, second and third segment of leg 3 endopodite of male, anterior. 


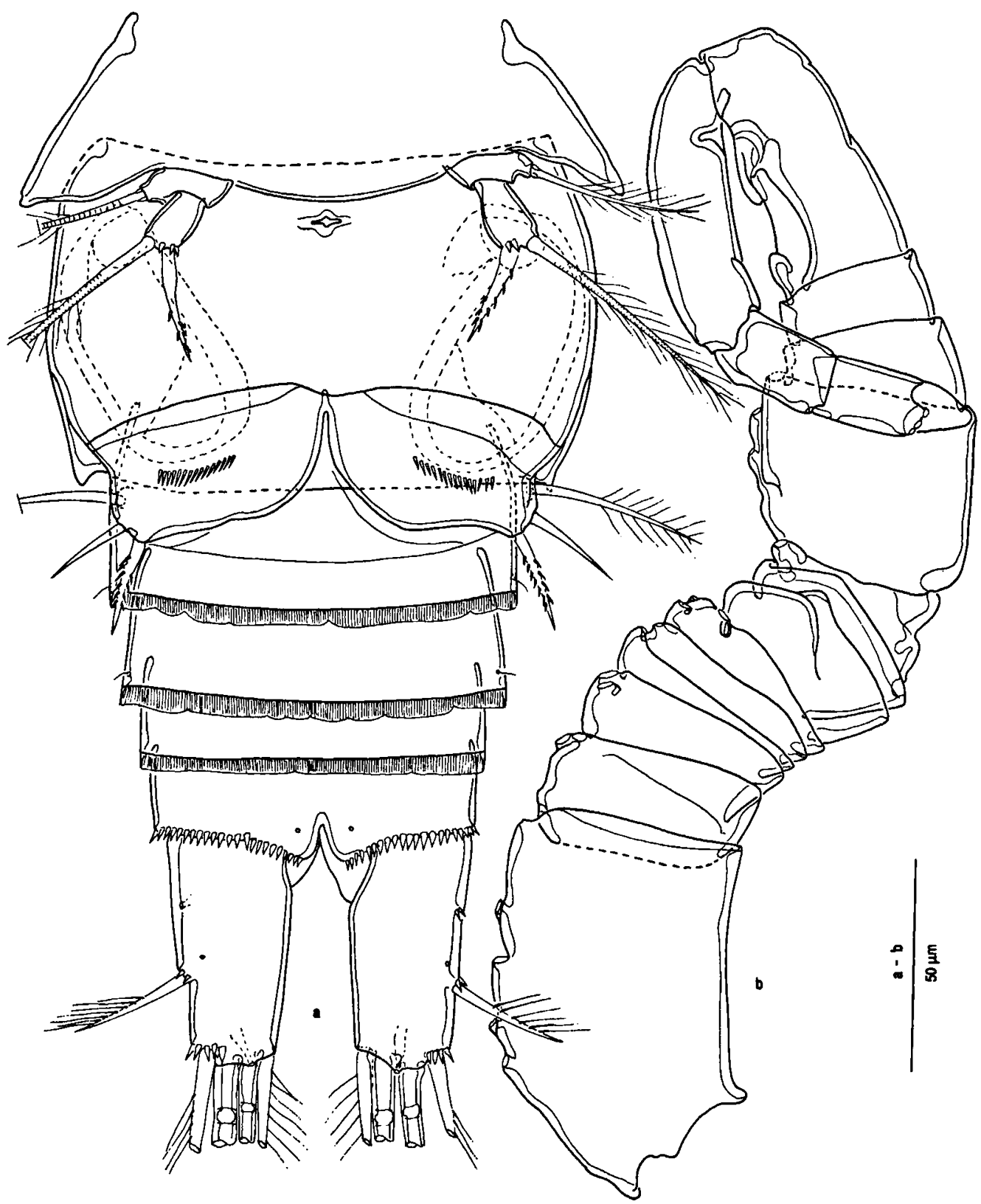

Fig. 7. Diacyclops chakan sp. n., allotype $\sigma^{\circ}$, COP 3864: a, fifth thoracic somite and urosomites, ventral; b, contour of antennule.

Diacyclops puuc Fiers, sp. n

(Figs. 8-10)

Synonymy. - Diacyclops sp. B, Suárez-Morales et al., 1996: 125, fig. 31. - ?Mesocyclops leuckarti Claus, 1857, of Wilson, 1936: 82, 85-88 (partim); Pearse \& Wilson, 1938: 153 (partim).

Type-specifications. - Single $९$ (holotype) dissected on three slides, COP 3919a, b, c. Type-locality: Hubicu Cenote (Yucatán), $6 \mathrm{~km}$ from Temozon Village beside dirt road leading to unnamed ranch. Coordinates $20^{\circ} 49.132^{\prime} \mathrm{N}, 8^{\circ} 10.348^{\prime} \mathrm{W}$. Closed cenote in form of cone, with $1.5 \mathrm{~m}$ diameter open roof, $40 \mathrm{~m}$ diameter lake $25 \mathrm{~m}$ below ground surface; sample from close to walls, 0-15 m deep; sample Mex 94-16, 18 April 1994, leg. Joaquín Vargas and Miguel Herrera. Additional copepod fauna: calanoids, Macrocyclops albidus s. str., COP 3922; sub- 

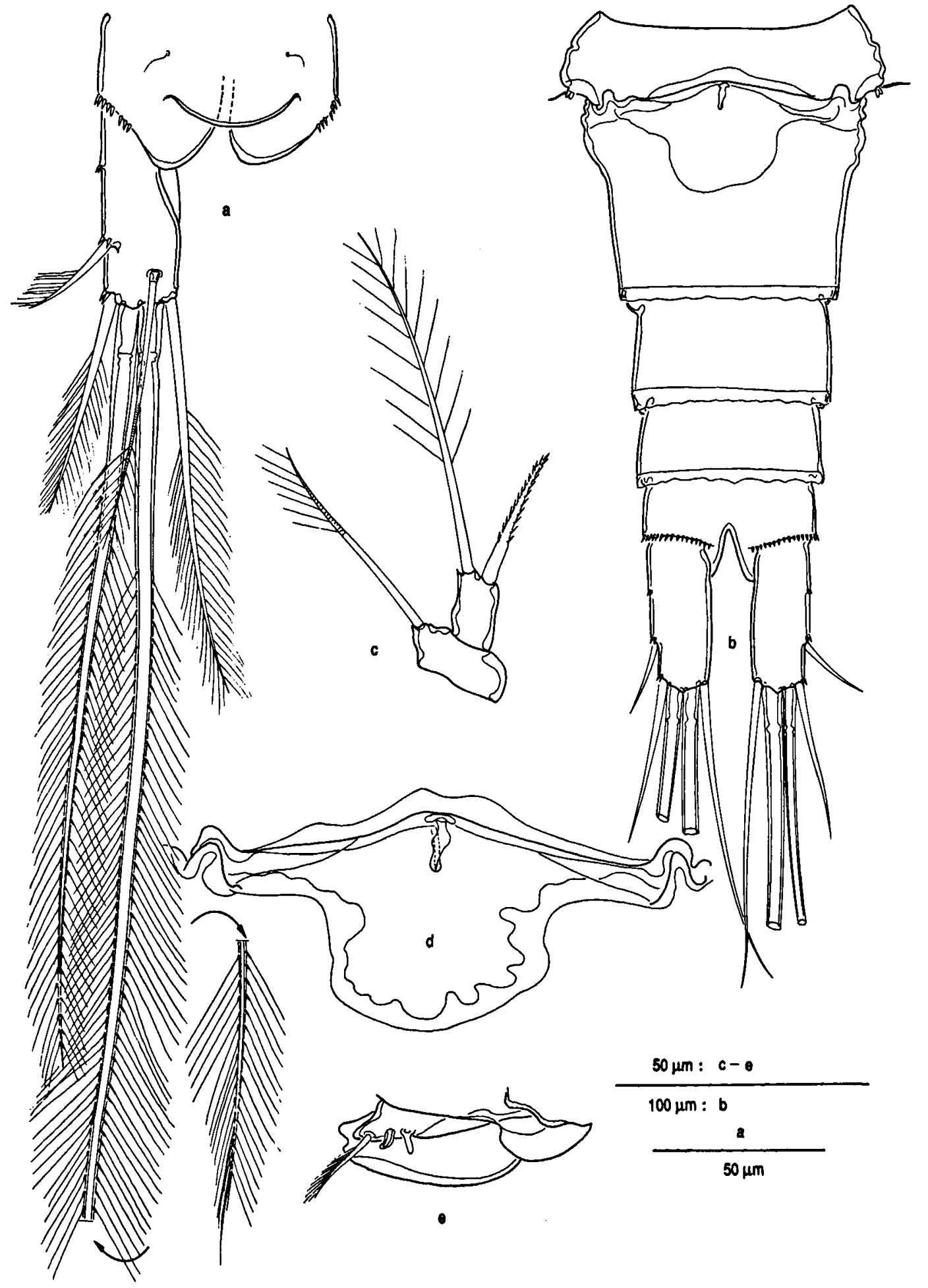

Fig. 8. Diacyclops puuc sp. n., holotype ९, COP 3919a-c: a, anal somite and left caudal ramus, dorsal; b, abdomen, ventral; c, leg 5; d, genital field; e, leg 6 . 


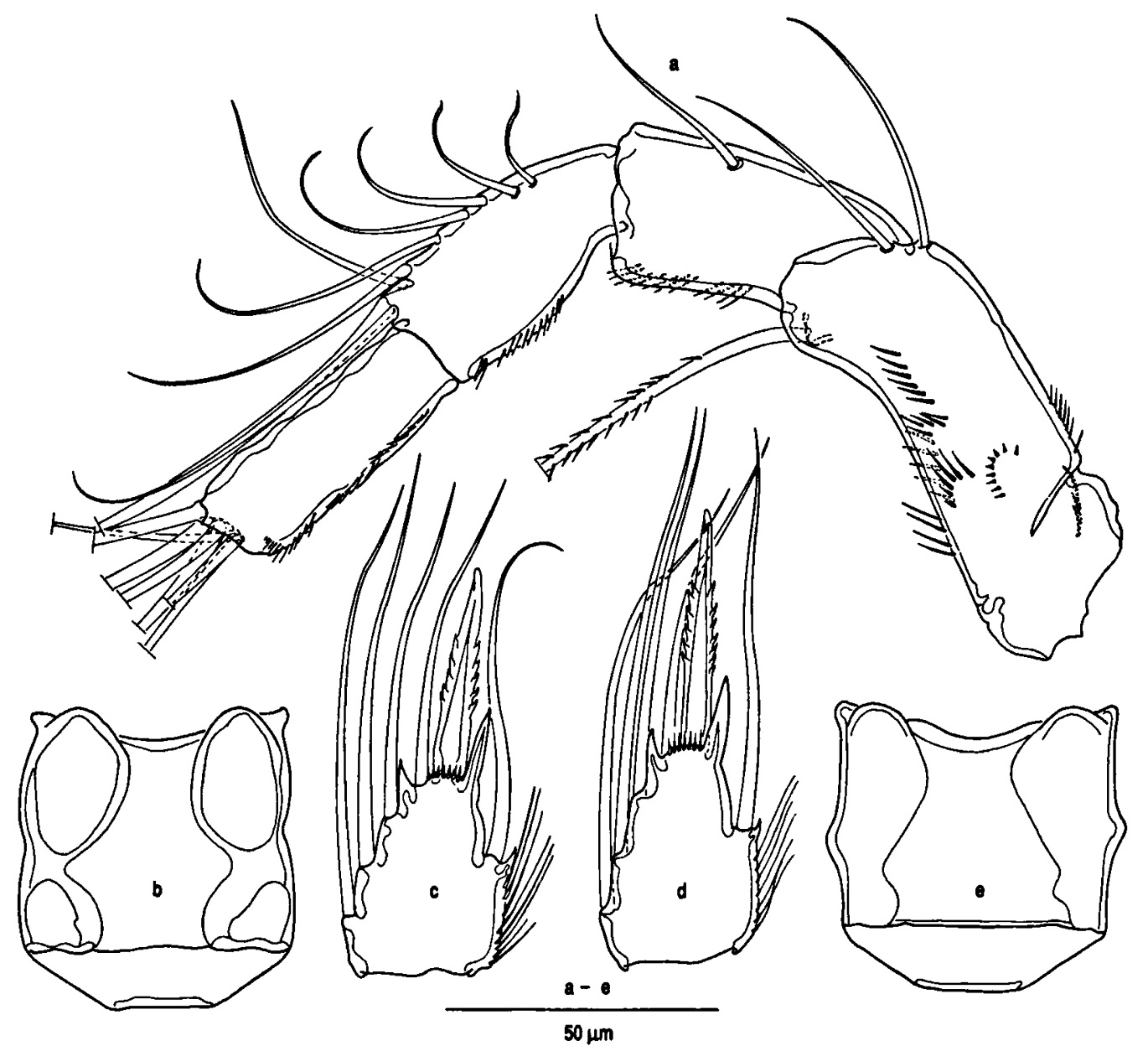

Fig. 9. Diacyclops puuc sp. n., holotype \&, COP 3919a-c: a, antenna, caudal; b, leg 1 coupler, frontal; c, third endopodal segment of leg 2, frontal; d, third endopodal segment of leg 3, frontal; e, leg 2 coupler, frontal (setal ornamentation not drawn).

species of Tropocyclops prasinus s. I., COP 3904; other crustacean fauna: ostracodes.

Description of female. - Remark: because the present species resembles $D$. chakan in many aspects, only the differences between both species are described below.

Body length $812 \mu \mathrm{m}$, with rounded pleurotergite, not posteriorly produced, of pedigerous somite 5 . Seminal receptacle (Fig. $8 \mathrm{~b}, \mathrm{~d}$ ) almost as in $D$. chakan, but posterior part more linguiform and less produced posteriorly.

Caudal rami (Fig. 8a) 2.55 times as long as wide. Lateral terminal seta $(68 \mu \mathrm{m})$ slightly longer than ramus, and medial terminal seta $(119 \mu \mathrm{m})$ fully twice as long as ramus.
Antennule 11-segmented, without indications of vestigial articulations. Segments (Roman numerals) with number of setae (Arabic numerals), spines and aesthetascs in parentheses: I (8), II (4), III (8), IV (3), V (1+spine), VI (2), VII (3), VIII (2+aesth.), IX (2), X (3), XI (7+aesth.). Aesthetasc on segment VIII reaching just beyond articulation with segment IX.

Basipodite of antenna (Fig. 9a) with, on caudal surface: 2 horseshoe-shaped rows of spinules (proximalmost row with 9 minute, medial row with 6 long spinules) in proximal half, and an irregular longitudinal row of 11 long spinules in distal half; on frontal surface: 1 short row of setules near proximal abexopodal margin and 1 median longitudinal 
row of long spinules near exopodal margin; abexopodal margin with slender spinules on proximal half, and exopodal margin with 4 long proximal setules.

Couplers of legs 1-4 smooth (Fig. 9b: leg 1; 9e: leg 2) and proportional lengths of segments and setae as in $D$. chakan. Terminal endopodal segments of leg 2 (Fig. 9c) and leg 3 (Fig. 9d) as illustrated. Leg 5 (Fig. 8c) closely resembling leg 5 of D. chakan, but terminal seta distinctly ( 2.5 times) longer than inner subterminal spine. Leg 6 (Fig. 8e) with 2 blunt elements and 1 short plumose seta.

Leg 1 coxopodite (Fig. 10a) with entire anterior surface smooth, except for 2 rows of minute spinules along distal margin; medial spine of basis reaching only to midlength of endopodite segment 2 ; outer spines on exopodite slender, with long hairlike attenuations, and setae also with attenuated naked tips (arrowed in illustration). Leg 4 coxopodite (Fig. 10b) with short transverse row of spinules on posterior face; exopodite spines slender, with smooth, slightly attenuated tips; terminal endopodite segment 1.6 times as long as wide, with proportional lengths of terminal spines as in $D$. chakan.

Etymology. - The species is named after the magnificent Mayan post-classical architectural style Puuc, characteristic for the region containing the type-locality of the species.

Discussion and comparisons. - Diacyclops puuc shares many characteristics with $D$. chakan and the differences seem to be a matter of dimensions and proportional lengths of appendages. Diacyclops puuc is much larger than its congener $(812 \mu \mathrm{m}$ vs. $613 \mu \mathrm{m})$ and has a rather short medial spine on leg 1. Diagnostic for $D$. puuc is the denser spinule pattern on the antennal basipodite. Whereas the spinule ornamentation on the caudal side of the basipodite in $D$. chakan is very reduced, in $D$. puuc it consists of three well-defined rows.

In the large genus Diacyclops, few species have all rami of the swimming legs 3-segmented, together with an 11-segmented antennule in the female. The only described species in North America with these attributes, D. jeanneli putei (Yeatman, 1943) has the middle segments of the endopodites of legs 1, 3 and 4 each with only one medial seta, and the leg 4 endopodite segment 3 with a medial terminal seta and a lateral terminal spine. In the Tibetan D. tenuispinalis (Shen \& Sung, 1963), the setation of the swimming legs is incompletely described. This species has a long caudal ramus (about 6.5 times longer than wide) and differs in other ways from $D$. chakan and D. puuc. All three species of the antipodean $D$. michaelseni - group also have 3-segmented swimming legs and 11 -segmented antennules. Two of these, $D$. michaelsen $i$ (Mrázek, 1901) and D. cryonastes Morton, 1985, differ from $D$. chakan and $D$. puuc in having the leg 1 endopodite segment 2 with only 1 seta (legs 2-4 endopodite segment 2 each has 2 setae); also, in at least $D$. cryonastes and $D$. michaelseni the leg 4 coupler and the basal segment of leg 5 of the female are ornamented with rows of spines. These attributes were described by Morton (1985) for $D$. cryonastes, which is known from Tasmania and extreme southeastern Australia. Their presence was confirmed by inspection of specimens of $D$. michaelseni from Tierra del Fuego (USNM 264526), of which D. skottsbergi (Lindberg, 1949) from South Patagonia is a synonym (Menu-Marque, 1991). As incompletely described by Borutzky \& Vinogradov (1957), D. mirnyi, the Antarctic member of the michaelseni-group, differs from $D$. chakan and $D$. puuc in having a longer caudal ramus (4.5-5 times longer than wide) and slightly in the shape of the seminal receptacle.

Segmentation of the antennule is variable in some species of Diacyclops, and the articulation of segment III in the holotype of $D$. chakan (forming a 12-segmented antennule) and the remnants of articulations in segments VII and VIII suggest that some populations could have an antennule with 12 , 14 or 15 segments. The only other species in the Americas with a 12-segmented antennule and swimming legs all 3-segmented is $D$. crassicaudis (Sars, 1863) s. 1., which is a much grosser, more heavily sculptured benthic species lacking a medial spine on the leg 1 basipodite and with a more slender caudal ramus than $D$. chakan and $D$. puuc. No American Diacyclops has an antennule with 14 or 15 segments.

The modified ornamentation of the setae of the leg 3 endopodite and the different length of the 


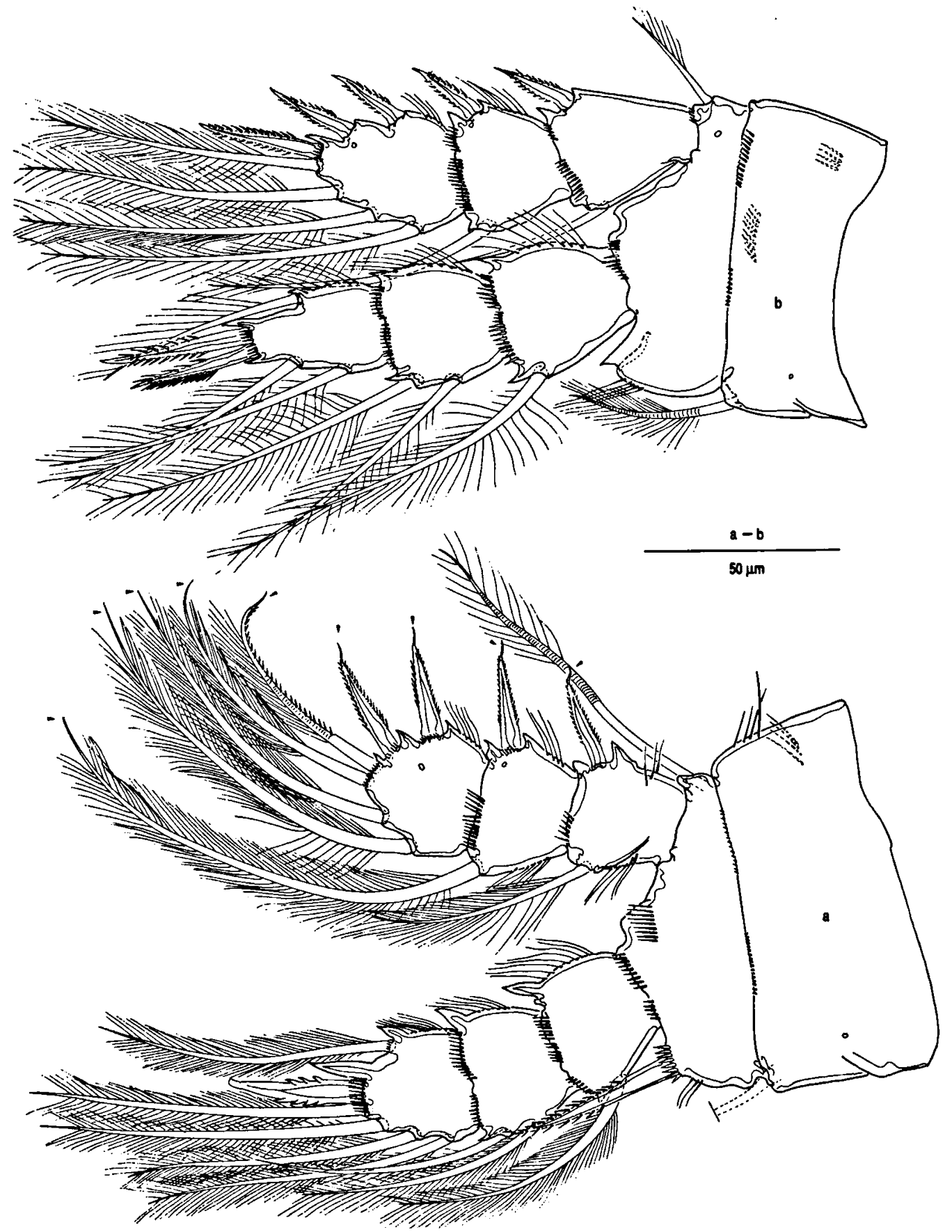

Fig. 10. Diacyclops puuc sp. n., holotype \&, COP 3919a-c: a, leg 1, frontal; b, leg 4, frontal.

terminal leg 2 endopodal spine in the male of $D$. chakan (also expected to occur in $D$. puuc) seem to be unique features. Sexual dimorphisms in postmaxillipedal legs are known to occur generally in species of Halicyclops (cf. e.g. Da Rocha, 1991), but have been rarely reported in other cyclopoid genera. In Diacyclops, so far only $D$. dimorphus Reid \& Strayer, 1994, and to some extent $D$. virgi- 
nianus Reid, 1993a possess sexual dimorphism in the swimming legs, but in the segmentation of the leg 4 exopodite. Re-examination of males of $D$. bisetosus (Rehberg, 1880), D. bicuspidatus (Claus, 1857) s. 1. and D. languidus (G.O. Sars, 1863) from Belgian localities revealed no indications of dimorphic ornamentation on the post-maxillipedal legs. However, because descriptions of cyclopoids are generally based on female morphology, other examples of modified setae in male natatorial legs may have been overlooked. As will be seen in the description of $M$. chaci, in males the distalmost endopodal setae may be quite different in length from the corresponding structures of the female. Dahms \& Fernando (1993) discovered sexual dimorphisms in the shape and length of several spines and setae on the post-maxillipedal legs of Mesocyclops leuckarti, although not at the same locations as in D. chakan and $M$. chaci.

Few species of the genus Diacyclops are known from tropical regions, and records from the neotropics are scarce. Only D. bernardi (Petkovski, 1986) has been previously recorded from Mexico, from a pond near Mérida, State of Yucatán (Reid, 1993b). The same species is also known from Isla San Andrés, Colombia, and from Louisiana, southern U.S.A. (Petkovski, 1986; Reid, 1993b). Diacyclops hispidus Reid, 1988 was collected near the Pacific coast of Colombia, and a similar, as yet undescribed species from northeastern Brazil (Reid, unpublished data). Dussart \& Defaye (1985) gave a record of the European $D$. bisetosus from Cuba, which was repeated by Reid (1990), but this record is in error (B. Dussart, in litt. to J.W. Reid). Marten et al. (1994) reported a single unidentifiable copepodid of Diacyclops sp. from Honduras. Diacyclops bernardi, $D$. hispidus, and $D$. bisetosus all have the antennule of the female of 16 or $17 \mathrm{seg}$ ments, among other differences from the two new species.

We infer from the collection information that both $D$. chakan and $D$. puuc are benthic crevicular species. Because of our present poor understanding of the systematics of Diacyclops, it is rather chancy to speculate about their possible closest relatives. The two benthic neotropical species $D$. hispidus and $D$. bernardi may share a common ancestor with the two Diacyclops species described here. These four species resemble each other in having threesegmented rami and identical spination and setation of the swimming legs, the leg 1 basipodite with a spine, a membrane present on the terminal two antennule segments $(D$. hispidus has a narrow serrate membrane on segments XVI and XVII rather than only on XVII as reported by Reid, 1988), the exopodite seta of the antenna present, and no reductions in the mouthparts. However, $D$. hispidus and $D$. bernardi are relatively robust, with the antennule of 16 or 17 segments, the length relationships of the terminal caudal setae different and the caudal setae relatively much shorter, more elaborate ornamentation on the antenna and legs 1-4 basipodites, stouter swimming legs with robust spines and relatively short setae, and the distal margins of the legs $1-4$ couplers more developed, the leg 4 coupler of $D$. bernardi with two dentiform processes, and the leg 5 spine much longer. Diacyclops hispidus has the medial surface of the caudal ramus ornamented with tiny spines. Diacyclops bernardi has a tendency toward reduction of the number of segments of the antennule, having 17 or more usually 16 (Reid, 1993b).

The only feature in D. chakan and D. puuc that is more usual in benthic than in planktonic animals is the 11-segmented antennule (Reid \& Strayer, 1994). The reduced antennule supports an hypothesis that both Diacyclops are derived from some benthic ancestor resembling $D$. bernardi and $D$. hispidus. However, two arguments indicate that $D$. chakan and $D$. puuc may share a common ancestor with a planktonic species. First, the presence of atavistic remains of articulations in segments III, VII and VIII in several specimens of $D$. chakan lead us to suppose that the 11-segmented antennule was derived directly from a 16- or 17-segmented antennule. The second indication may be the relatively long antennule of both species, which reaches the middle of the second thoracic somite. In most interstitial species (Reid \& Strayer, 1994) and in European hypogean species such as D. languidus s. 1. and D. languidoides (Lilljeborg, 1901) s. 1. (F. Fiers, personal observations), the antennule does not reach beyond the posterior margin of the cephalothorax, being usually only as long as $2 / 3$ of the cephalothorax length.

Wilson (1936 and in Pearse \& Wilson, 1938) re- 
ported Mesocyclops leuckarti from (respectively) 27 and 10 cenotes and other localities near Mérida in Yucatán. The new Diacyclops and Mesocyclops species, as well as $M$. reidae and (more sporadically) $M$. longisetus var. curvatus Dussart, 1987 appear to be widely distributed in the cenotes near Mérida. It is likely that Wilson misidentified some or all of them as $M$. leuckarti, which was at that time poorly defined and presumed to be cosmopolitan.

\section{Genus Mesocyclops G.O. Sars, 1914}

\section{Mesocyclops yutsil Reid, sp. n}

(Figs. 11-15)

Synonymy. - Mesocyclops sp. A, Suárez-Morales et al., 1996: 131-132, figs. 37-39. - ?Mesocyclops leuckarti Claus, 1857 of: Wilson, 1936: 82, 85-88 (partim); Pearse \& Wilson, 1938: 153 (partim).

Type-specifications. - Holotype \&, USNM 259843; allotype $\circ$, USNM 259844, each dissected on 1 slide in PVL, from Yuncu Cenote, Yuncu (Yucatán), depth 15-30 m, sample 93046, leg. T.M. Iliffe, 10 July 1993. Paratypes: $1 \%$, dissected on slide, USNM 259845, and $3 \%$, $1 \sigma^{\circ}$ and 20 copepodids, USNM 259846, sample 93-046. - Site description and additional copepod fauna: see under D. chakan.

Noc Ac Cenote, a freshwater cave located $1 \mathrm{~km}$ south of the village of Noc Ac (Yucatán), $4 \%$ \%, 1 \%, 4 copepodids. Coordinates $21^{\circ} 04^{\prime} 45^{\prime \prime} \mathrm{N}, 89^{\circ} 43^{\prime} 15^{\prime \prime} \mathrm{W}$. A circular, $4 \mathrm{~m}$ diameter sinkhole entrance drops $3 \mathrm{~m}$ vertically into a clear pool, $3 \mathrm{~m}$ or more deep. The rock surrounding the entrance sinkhole is undercut to form a room $22 \mathrm{~m}$ long by $14 \mathrm{~m}$ wide at water level. Detrital organic matter and large breakdown boulders cover most of the bottom. At opposite ends of the pool, segments of the cave continue down over breakdown to 35 and $21 \mathrm{~m}$ depths, but no passage development was found. Numerous fish are present in all sections of the entrance pool. Sample taken with plankton net at 10-15 m depths. Sample 93-044, leg. T.M. Iliffe, 7 July 1993, USNM 259847. - Additional copepod fauna: subspecies of Tropocyclops prasinus s. l., 1 \&, USNM 278026; marine cyclopoids, harpacticoids, misophrioids; other crustacean fauna: isopods (Creaseriella anops) and shrimp (Typhlatya sp.), collected from the deeper waters in darkness.

Mucuyché Cenote, Mucuyché (Yucatán), 2 \& \&, 2 copepodids, depth 20-30 m, sample 93-045, leg. T.M. Iliffe, 9 July 1993, USNM 259848. Site description and additional copepod fauna: see under $D$. chakan.

Additional material. -

(1) Yuncu Cenote (Yucatán), depth 0-5 m, sample 94-023, leg. T.M. Iliffe, 13 August 1994: 72 ९ ९, 1 ơ, 38 copepodids,
USNM 271861, and 30+ copepodids, USNM 271864. - Site description and additional copepod fauna: see under D. chakan. (2) Mayan Blue Cenote, anchialine cave located $3 \mathrm{~km}$ south of the village of Tulum Pueblo (Quintana Roo). Coordinates $20^{\circ} 11^{\prime} 38^{\prime \prime} \mathrm{N}, 8^{\circ} 29^{\prime} 50^{\prime \prime} \mathrm{W}$. Mayan Blue is part of the $18.5 \mathrm{~km}$ long cave system Systema Naranjal. Primary orientation of the cave is perpendicular to the coast, suggesting that it serves as a major drainage conduit to the sea. Cave passages are predominantly developed at the halocline in $17 \mathrm{~m}$ water depth, where mixing corrosion between fresh and salt water occurs. Salinity of water above the halocline averages less than $2 \%$, while below the abrupt halocline, salinity is $35 \%$. Sample taken with plankton net from water column in 10-20 m depths of cave interior. Sample 94-025B, leg. T.M. Iliffe, 16 August 1994: 3 copepodids, USNM 271860. - Additional copepods: diaptomids, 1 misophrioid.

(3) Najarone Cenote, Tulum (Quintana Roo), anchialine cave located $3 \mathrm{~km}$ south of Tulum Pueblo. Coordinates $20^{\circ} 12^{\prime} 01^{\prime \prime} \mathrm{N}$, $87^{\circ} 30^{\prime} 01^{\prime \prime} \mathrm{W}$. This cave is situated upstream (farther inland) from Mayan Blue and is also part of the Systema Naranjal. Chac's Room is a large dome room $450 \mathrm{~m}$ into the cave from the entrance pool. Sample taken with plankton net from water column in 16-18 m depths of cave interior and 6-10 m depths of Chac's Room. Sample 94-027, leg. T.M. Iliffe, 20 August 1994: Mesocyclops cf. yutsil, 1 \& copepodid stage V (poor condition), USNM 271859. - Additional copepods: marine cyclopoids, harpacticoids.

(4) 27 Steps Cenote, Akumal (Quintana Roo), coordinates $20^{\circ} 24^{\prime} 21^{\prime \prime} \mathrm{N}, 87^{\circ} 19^{\prime} 39^{\prime \prime} \mathrm{W}$, a cave about $1.5 \mathrm{~km}$ west of main highway at Akumal, consisting of a $30 \mathrm{~m}$ long by $20 \mathrm{~m}$ wide by $8 \mathrm{~m}$ deep sinkhole with a pool along the undercut edges of the pool and three passages leading off under water. The far passage extends to a $12 \mathrm{~m}$ diameter air-filled dome room containing many tree roots. Sample taken from surface water in air dome at 0-5 m depth. Sample 95-021, leg. T.M. Iliffe, 27 July 1995: 1000+ (mainly copepodids), USNM 264232. - Additional copepods: Mastigodiaptomus texensis (M.S. Wilson, 1953), 100+ (mainly copepodids, nauplii), USNM 264233.

(5) Gruta Tzab-Nah (or Dzab-Nah), Tecoh (Yucatán), $2 \mathrm{~km}$ south of the village of Tecoh on the road to Telchaquillo; entrance is $100 \mathrm{~m}$ east of road. Coordinates $20^{\circ} 44^{\prime} 50^{\prime \prime} \mathrm{N}$, $89^{\circ} 28^{\prime} 40^{\prime \prime} \mathrm{W}$. A walking passage in the cave leads to a bridge across a $7 \mathrm{~m}$ deep chasm with a lake at the bottom, then past several deep fissure pools to a $30 \mathrm{~m}$ diameter lake. Under water, the sandy bottom of the lake slopes down to a $20 \mathrm{~m}$ wide submerged cave entrance at $15 \mathrm{~m}$ depth. This underwater passage of solutional origin continues for $130 \mathrm{~m}$ to $33 \mathrm{~m}$ depth where it abruptly ends. While the water in this section of the cave is exceptionally clear, other pools in the cave are murky with a thick scum at the surface, apparently from liquid organic wastes from a nearby henequen (sisal) processing plant. Sample collected with plankton net from water column of last lake at 0-6 m depths. Sample 91-021A, leg. T.M. Iliffe, 27 June 1991: $4 \& \&$ and $1 \%$, USNM 274244. - Additional copepod fauna: Mesocyclops chaci, see below; and crustacean fauna: ostracodes, Creaseriella anops, thermosbaenaceans.

Description of female. - Lengths $(\mu \mathrm{m})$ of holotype, 


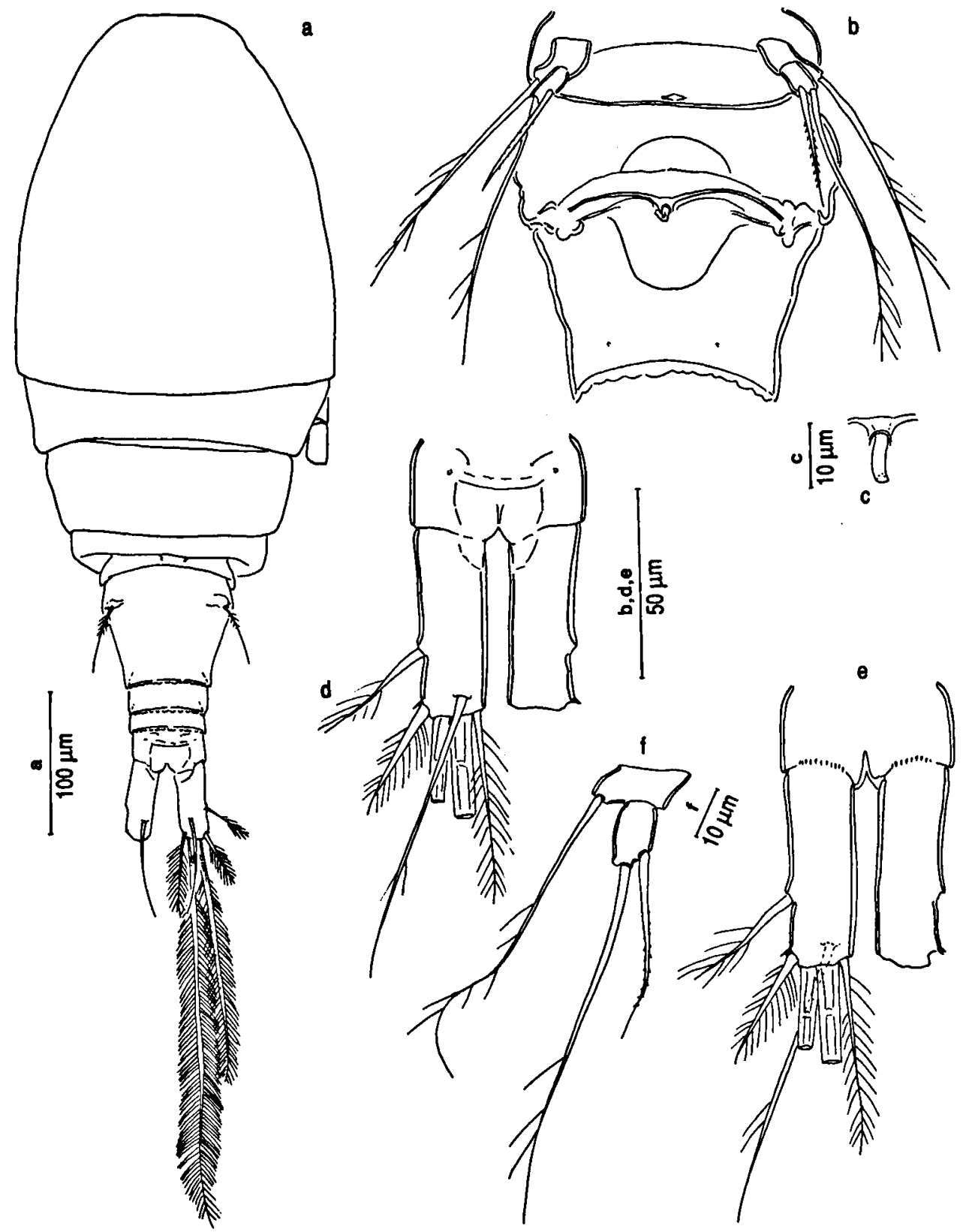

Fig. 11. Mesocyclops yutsil sp. n., a, paratype \&, Noc Ac Cenote, USNM 259847; b-f, holotype $\%$, Yuncu Cenote, USNM 259843: a, habitus, dorsal; b, pedigerous somite 5 and genital double somite, ventral; c, copulatory pore and pore canal; d, anal somite and caudal ramus, dorsal; e, anal somite and caudal ramus, ventral; $f$, leg 5.

590, of 4 paratypes from Yuncu, 536, 568, 590, 612; of 3 females from Noc Ac, 588, 592, 612; of 1 female from Mucuyché, 608. (Some individuals from each cenote partly decomposed, not measured). Habitus (Fig. 11a) in dorsal view slender, posterolat- eral margins of pedigerous somite 4 rounded. Pedigerous somite 5 without surface ornament except pair of dorsal sensilla. Genital double somite (Fig. 11b) slightly longer than wide, anterior $2 / 3 \mathrm{ex}-$ panded; without visible surface ornament except 


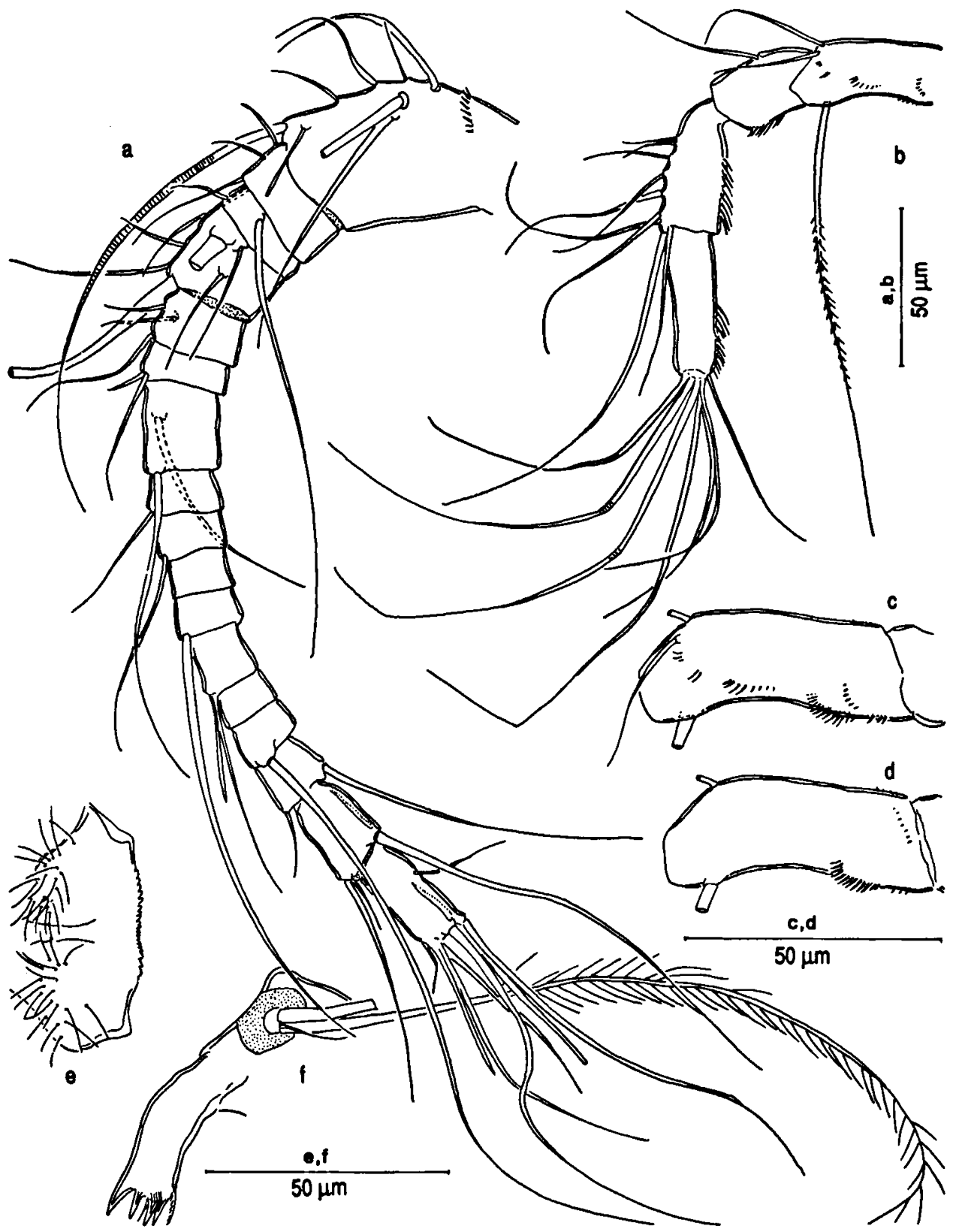

Fig. 12. Mesocyclops yutsil sp. n., a-d, f, holotype \&, Yuncu Cenote, USNM 259843; e, paratype Q, Yuncu Cenote, USNM 259845 a, antennule; b, antenna; $c$, antenna basipodite, caudal; $d$, antenna basipodite, frontal; $e$, labrum, frontal; $f$, mandible.

pair of sensilla near posteroventral border. Seminal receptacle (Fig. 11b) with rounded anterior and posterior expansions; lateral arms broad; copulatory pore slightly sclerotized, pore canal (Fig. 11c) short, broad, curved dorsally from pore. Hyaline borders of urosomites (Fig. 11a, b) weakly crenu- late. Anal somite (Fig. 11d, e) naked except for pair of dorsal sensilla, pair of dorsal pores, and row of small spines on posteroventral margin above each caudal ramus; anal operculum wide, slightly crescentic, unsclerotized. Caudal ramus (Fig. 11a, d, e) 3.0 times longer than wide; medial surface 


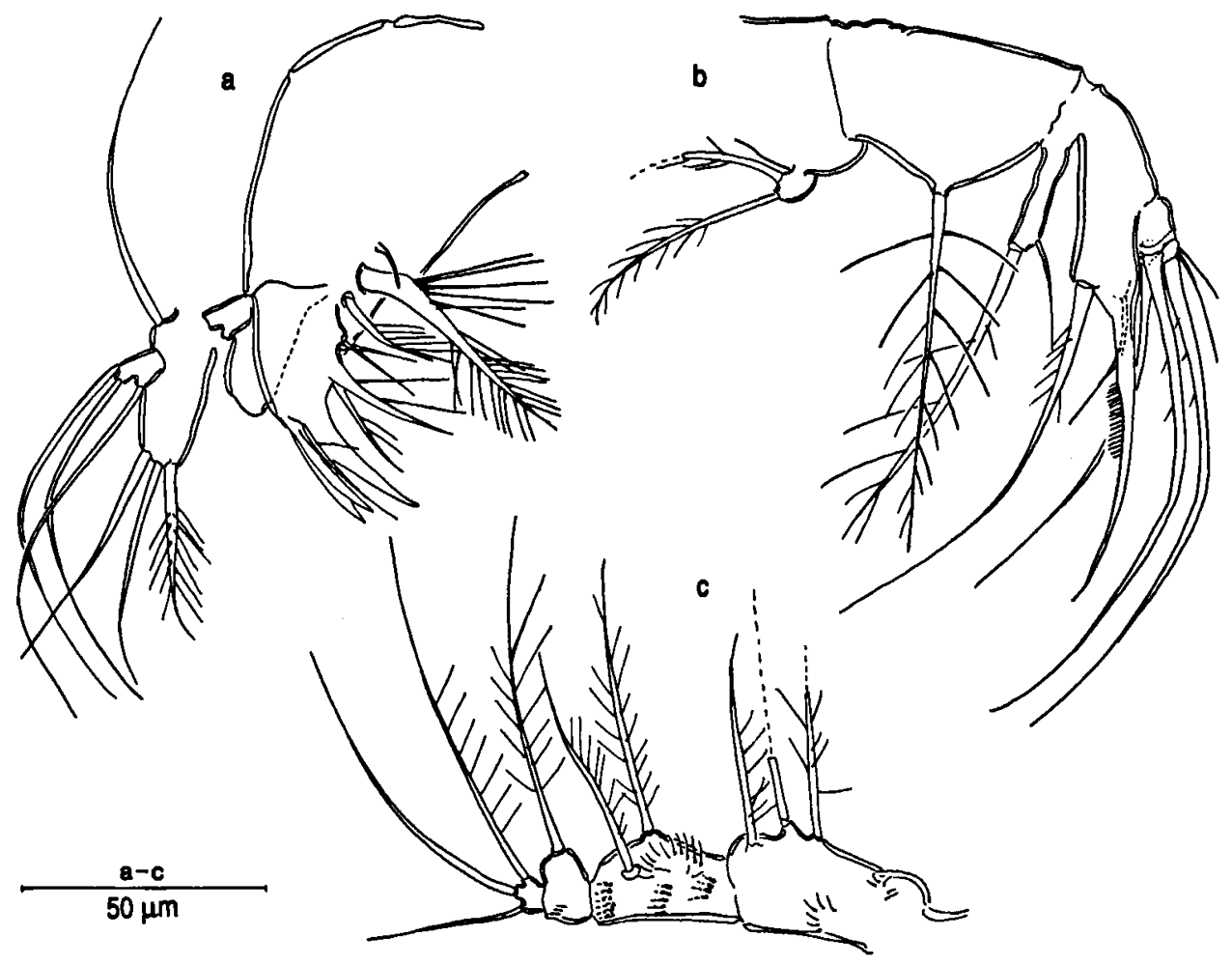

Fig. 13. Mesocyclops yutsil sp. n., holotype \&, Yuncu Cenote, USNM 259843: a, maxillule; b, maxilla; c, maxilliped.

naked; ornamented only with few tiny spines at base of lateralmost terminal caudal seta. Lateral seta inserted at posterior third of ramus. All caudal setae with fine plumage, plumage of dorsal seta sparse. Lengths of caudal setae of holotype $(\mu \mathrm{m})$ : lateral 40 , dorsal 92, lateralmost to medialmost terminal 35, 145, 292, 51. Dorsal caudal seta of paratypes from Noc Ac (Fig. 11a) inserted slightly more anteriorly on caudal ramus than in populations from Yuncu and Mucuyché, and relatively shorter, but still longer than lateralmost terminal caudal seta.

Antennule (Fig. 12a) of 17 segments, reaching just past distal margin of pedigerous somite 2 or to mid-pedigerous somite 3. Segments (Roman numerals) with number of setae (Arabic numerals), spines and aesthetascs in parentheses: I (8), II (4), III (2), IV (6), V (3), VI (1+spine), VII (2), VIII (1), IX (1), X (0), XI (1), XII (1+aesth.), XIII (0), IX (1), XV (2), XVI (2), XVII (7+aesth.). Aesthetasc on segment 12 reaching past distal end of seg- ment 14. Narrow serrate hyaline membrane on segments 16 and 17, on segment 17 extending from midlength seta to distal end of segment.

Antenna (Fig. 12b-d) of 4 segments. Basipodite with 3 setae, exopodite-seta long. Endopodite segment 2 with 8 setae on anterior margin in most specimens, holotype and 1 female from Noc Ac with additional proximal seta on 1 antenna; another female from Noc Ac with 9 setae on both antennae. Small spines on surface of basipodite arranged in basic pattern for Mesocyclops (cf. Van de Velde, 1984a, 1984b), except 3 longitudinal rows along posterior surface each composed of relatively few spines; additionally, 2 distal groups of 2-3 tiny spines.

Labrum (Fig. 12e) with 18 or 19 tiny teeth between little developed rounded lateral corners, and 2 groups of long hairs on frontal surface.

Mandible (Fig. 12f), palp with normal 2 long and 1 short setae; surface otherwise unornamented except row of hairlike spinules near distal teeth. 


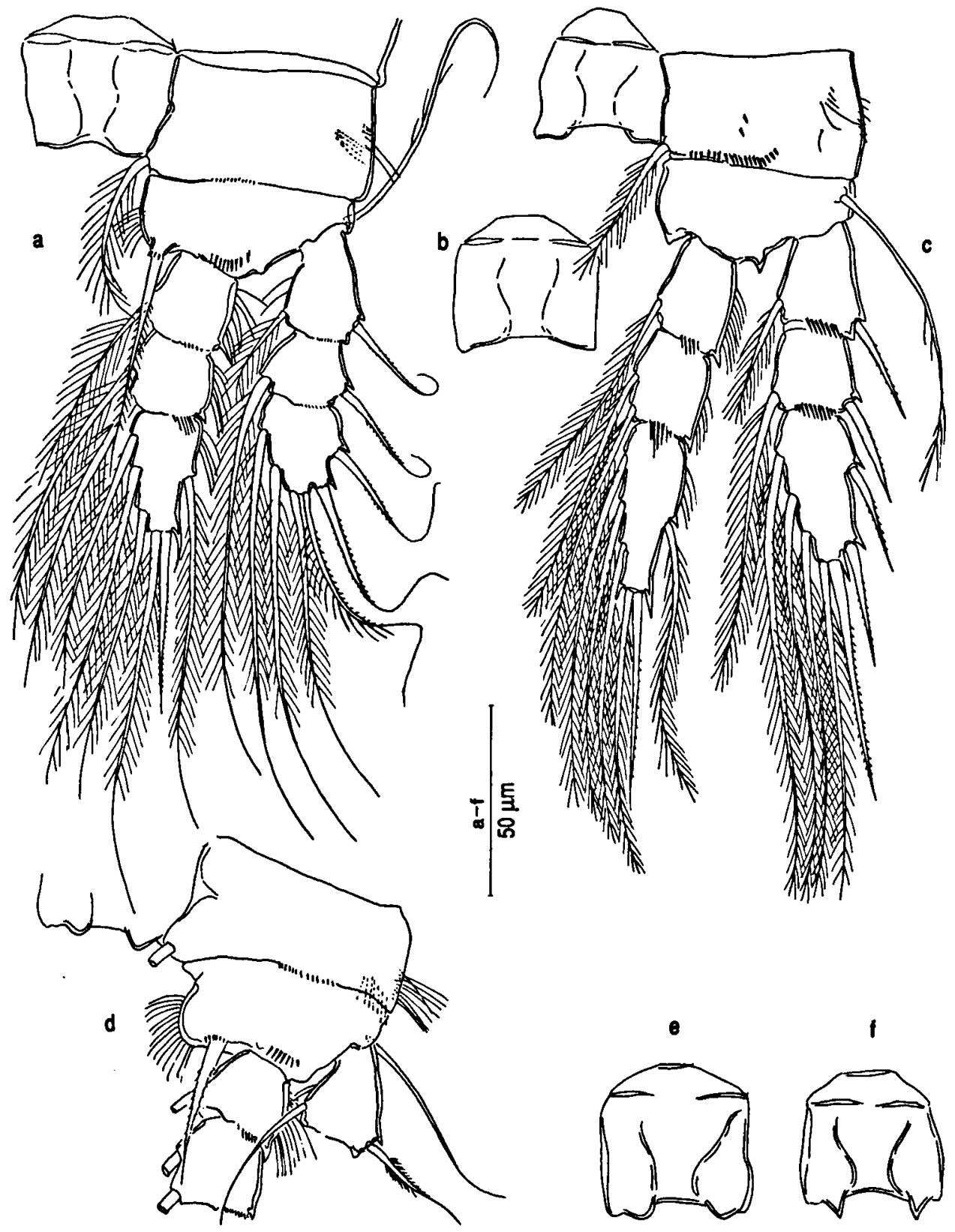

Fig. 14. Mesocyclops yutsil sp. n., a-c, holotype \&, Yuncu Cenote, USNM 259843; d-f, paratype \&, Noc Ac Cenote, USNM 259847: a, leg 1 and coupler, frontal; b, leg 2 coupler, caudal; c, leg 3 and coupler, caudal; d, proximal part of leg 1 and coupler, frontal; e, leg 2 coupler, frontal; f, leg 3 coupler, frontal.

Maxillule (Fig. 13a), palp lacking spines on surface; armament of coxa, precoxa and palp normal for genus except appendages longer and thinner than usual in Mesocyclops (cf. M. leuckarti, as redescribed by Dahms \& Fernando, 1993), and next distalmost seta of precoxa long, plumed.

Maxilla (Fig. 13b) slender with attenuate appendages; coxa without spines on surface; claw of basis with row of slender "teeth" along about middle third of length. 


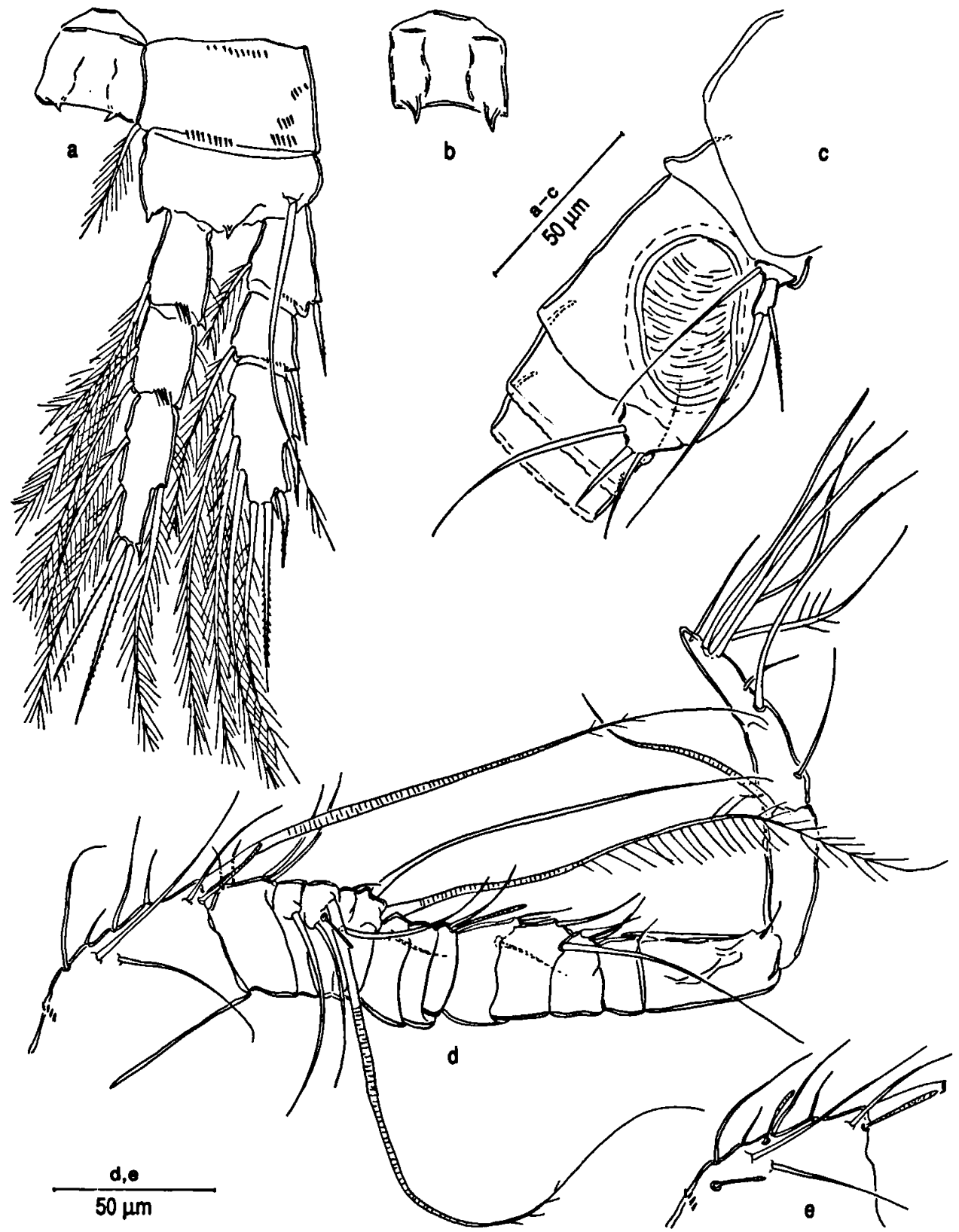

Fig. 15. Mesocyclops yutsil sp. n., a, holotype \&, Yuncu Cenote, USNM 259843; b, paratype \&, Noc Ac Cenote, USNM 259847; c, d, allotype $\sigma^{\prime}$, Yuncu Cenote, USNM 259844; e, paratype $\sigma$, Yuncu Cenote, USNM 259847: a, leg 4 and coupler, caudal; b, leg 4 coupler, frontal; c, posterior prosome and anterior urosome with legs 5 and 6, right lateral; $d$, antennule; e, semi-diagrammatic view of part of antennule segment I showing normal complement of aesthetascs.

Maxilliped (Fig. 13c) slender, basis rather short; setae long, attenuate; rows of small spines on coxa and basis, basis with 3 transverse rows of spines along outer surface.
Swimming legs $1-4$ (Figs. 14a-f, 15a, b) all with 3-segmented, slender rami; terminal segments of exopodites with 2, 3, 3, 3 spines and 4, 4, 4, 4 setae, respectively. No pores visible. Exopodite spines 
slender, spines of leg 1 with flexible whiplike tips; these tips longest in specimens from Mucuyché and Yuncu. Terminal spines of endopodites of legs 1-3 slender, nearly as long as terminal 2 segments combined. Most setae as long as or longer than rami, with thin whiplike tips; tips of setae of leg 1 bare, completely plumed in legs $2-4$. Couplers of all legs without surface ornament; in specimens from Yuncu, distal margins of couplers of legs 1-3 each with 2 slightly rounded expansions, expansions of leg 3 most pronounced; leg 4 coupler with 2 small medially directed dentiform expansions. In specimens from Mucuyché and Noc Ac, paired expansions more developed, expansions of leg 3 as well as of leg 4 acute. Leg 1 with plumed spine on medial expansion of basipodite; in Mucuyché and Yuncu specimens, this spine extremely slender, reaching past distal end of endopodite segment 2; in Noc Ac specimens, this spine slightly stouter, reaching nearly to distal end of endopodite segment 2 . Legs 2 and 3 similar except leg 2 slightly larger and segments of rami stouter; in holotype, spine on leg 2 exopodite 1 directed posteriorly like corresponding spine on leg 3 . In paratype specimens from all cenotes, spines on first segment of exopodites of legs 1 and 2 extended laterally; some slightly rotated; this extension and rotation more noticeable in leg 2. Leg 4 coxopodite with several rows of spines on posterior surface; medial expansion of basipodite bare. Leg 4 endopodite terminal segment 4 times wider than long; terminal spines slender, longer than segment, each finely spinulate along most of both margins; lateral terminal spine about 1.2 times longer than medial terminal spine. Setae of this segment reaching past ends of terminal spines in Mucuyché and Yuncu specimens, not quite to ends of terminal spines in Noc Ac specimens.

Leg 5 (Fig. 11b, f), basal segment broad, distinct from somite, bearing long lateral seta; distal segment with long plumed terminal seta and shorter, finely serrate slender spiniform seta which is inserted at distal third of medial margin of segment.

Leg 6 (Fig. 11a) consisting of small bare ovoid plate with 2 small spines and 1 long dorsal seta.

Egg sacs not present on any specimen examined.

Description of male. - Lengths $(\mu \mathrm{m})$ of allotype,
592; of paratype from Yuncu, 532; of paratype from Noc Ac, 588 (extended in lactic acid).

Habitus and appendages as female except for normal sexual dimorphism in antennule, urosome and leg 6, and as follows.

Antennule (Fig. 15d, e) geniculate, of $16 \mathrm{seg}$ ments. Segments 1, 4, 9, and 13 of both antennules each with 1 aesthetasc in both males from Yuncu. Paratype from Noc Ac with normal complement of aesthetascs on both antennules, specifically with 3 aesthetascs on segment 1 (Fig. 15e).

Antenna endopodite segment 2 with 7 setae on anterior margin in both males from Yuncu; with 8 setae in male from Noc Ac.

Leg 6 (Fig. 15c) consisting of small bare plate bearing long dorsal seta and 2 shorter spiniform setae, these subequal in length.

Etymology. - The species is named yutsil, meaning beautiful or graceful in Mayan, for the striking attenuate aspect of its appendages; proposed in apposition.

Discussion and comparisons. - Mesocyclops yutsil is discussed together with the following species, M. chaci.

Mesocyclops chaci Fiers, sp. n (Figs. 16-21)

Synonymy. - Mesocyclops sp. B, Suárez-Morales et al., 1996: 133-134, figs. 40-42. - ?Mesocyclops leuckarti Claus, 1857, of: Wilson, 1936: 82, 85-88 (partim); Pearse \& Wilson, 1938: 153 (partim).

Type-specifications. - Holotype $\$$, dissected on three slides in glycerine, COP 3813a, b, c. Allotype $\sigma$, dissected on three slides in glycerine, COP 3816a, b, c. Paratypes: 3 \& \&, dissected, mounted in glycerine (COP 3812a, b; COP 3814a, b, c and COP $3815 \mathrm{a}, \mathrm{b}, \mathrm{c}) ; 32$ ९ \&, $2 \sigma^{\circ} \sigma^{\circ}, 13$ copepodids, COP 3811 and COP 3817.

Type locality: permanently covered well with diameter of $1.5 \mathrm{~m}$ and depth $8 \mathrm{~m}$, containing $0.5 \mathrm{~m}$ water, at Cheuman (Yucatán), on the road from Caudel to Sierra Papacal, about 12 $\mathrm{km}$ N.W. from Mérida. Coordinates $21^{\circ} 03.859 \mathrm{~N}, 8^{\circ} 42.288^{\prime} \mathrm{W}$. Leg. F. Moravec, CINVESTAV-IPN (Mérida). Topographic map: Tizimín F16-7, Aguas subterráneas (27-8-83) indicates a chlorinity of $213.0 \mathrm{mg} / \mathrm{l}$.

Additional material. -

Gruta Tzab-Nah, Tecoh (Yucatán), sample 91-021A, leg. T.M. 


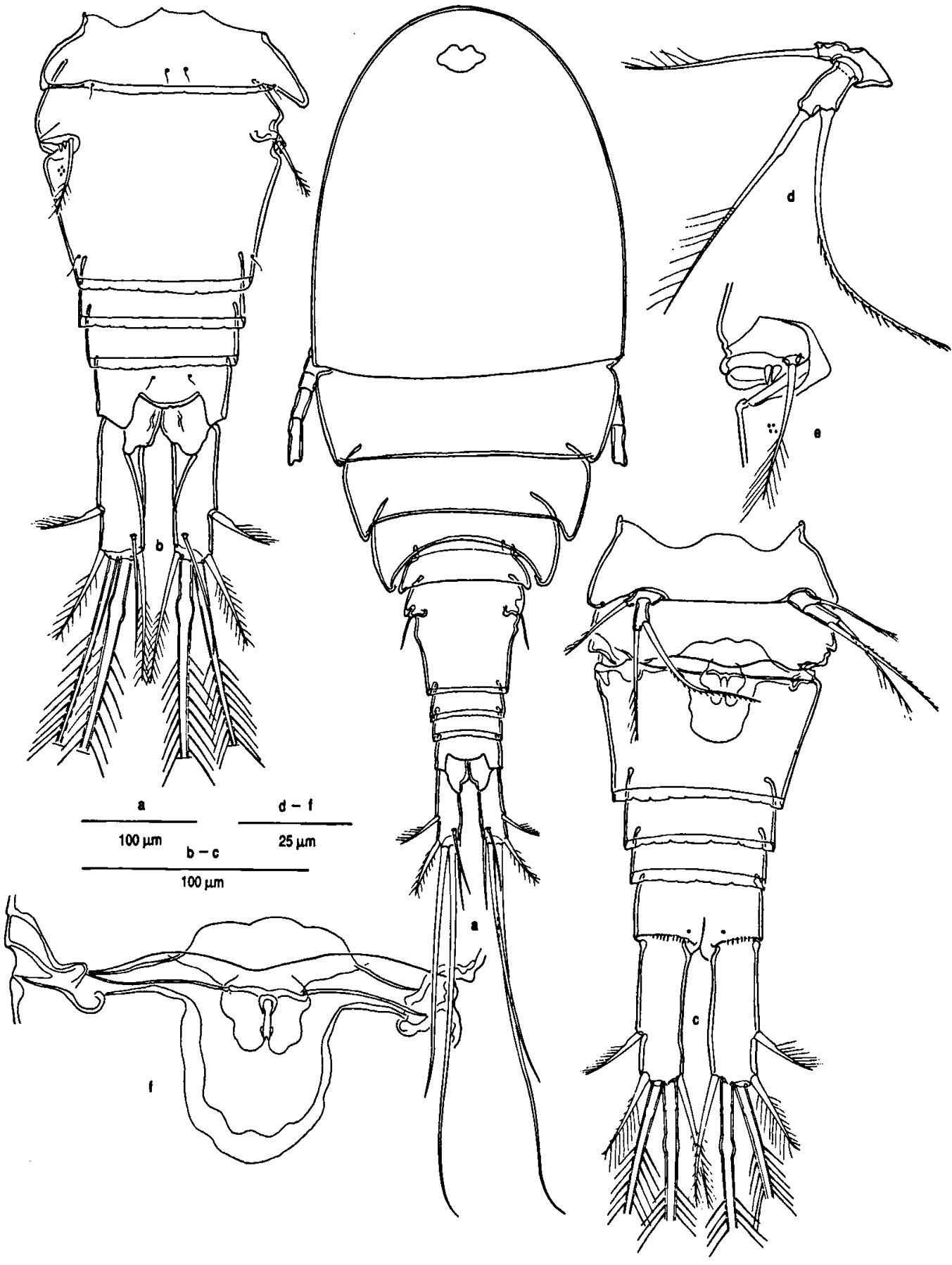

Fig. 16. Mesocyclops chaci sp. n., a, paratype \&, COP 3814; b, e, paratype \&, COP 3812; c-d, f, holotype \&, COP 3813: a, habitus, dorsal; b, abdomen, dorsal; c, abdomen, ventral; $d$, leg 5; e, leg 6; f, genital field. 


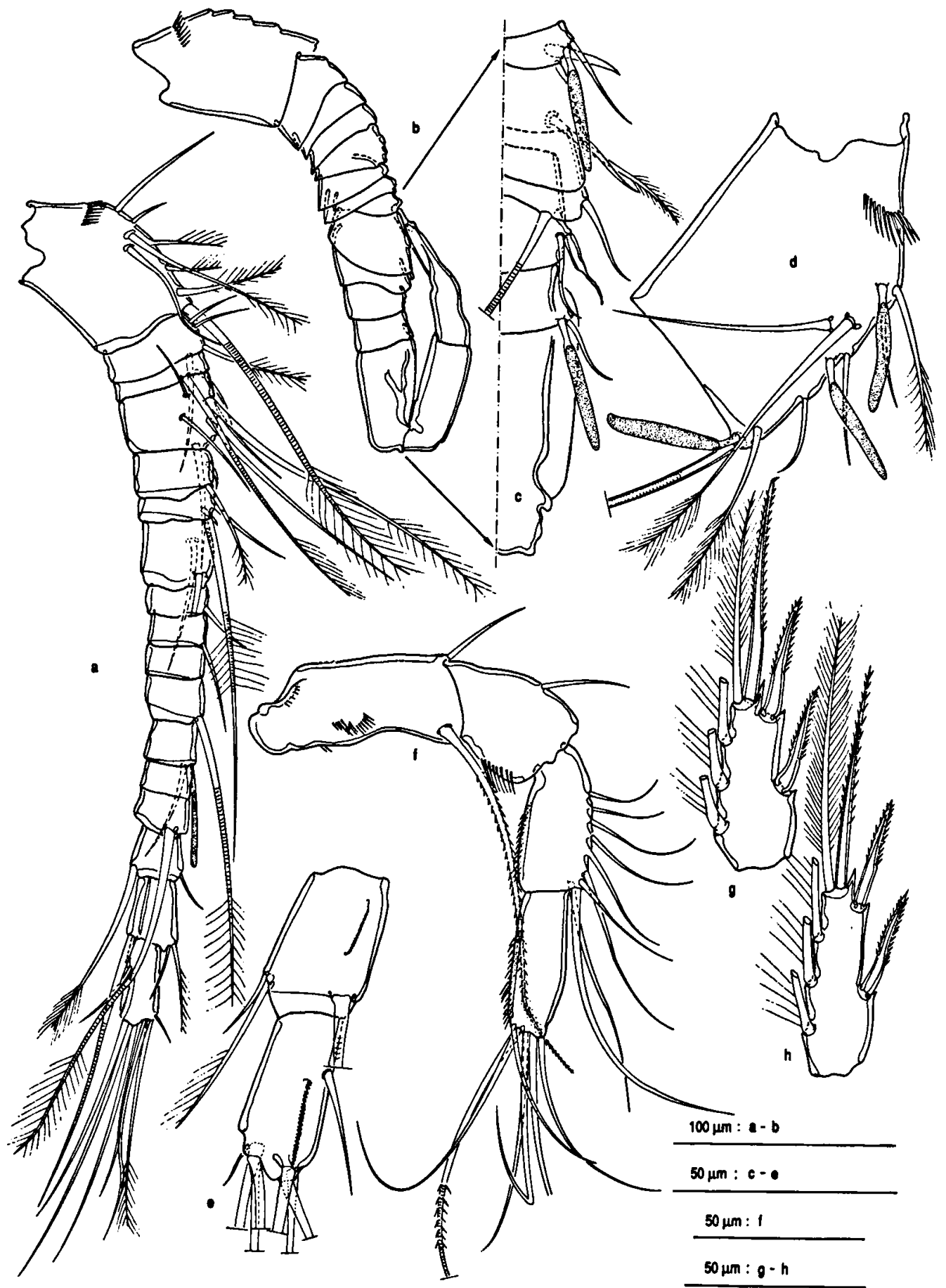

Fig. 17. Mesocyclops chaci sp. n., a, e, f, paratype 9 , COP $3814 ;$ b-d, g, h, allotype $\sigma^{\circ}$, COP 3815: a, antennule; b, contour of antennule; $c$, anterior side of segments VIII to XIII of antennule of male; d, segment I of antennule of male; e, segments XVI and XVII of antennule of female; $f$, antenna, frontal side; $g$, third exopodal segment of leg 3 of male; $h$, third exopodal segment of leg 4 of male. 
Iliffe, 27 June 1991: 4 १ ९, 1 ○’, USNM 274244. - Site description and additional copepod fauna: see under $M$. yutsil.

Description of female. - Length of holotype 730 $\mu \mathrm{m}$, ranging from 710 to $730 \mu \mathrm{m}$ in paratypes. Habitus (Fig. 16a) slender in dorsal view with lateral edges of pedigers 3 and 4 slightly posteriorly produced. Pediger 5 without surface ornament, except for usual 2 dorsal sensilla. Eye present, unpigmented (specimens fixed in $\pm 4 \%$ formalin, drawn only few days later). Genital double somite (Fig. $16 \mathrm{~b}, \mathrm{c}$ ) wider than long (L/W ratio: $0.77: 1$ ). Posterior margins of genital double somite and abdominal somites each with weakly incised hyaline fringe. Seminal receptacle (Fig. 16f) with rounded anterior and posterior expansions; lateral arms broad, nearly perpendicular to longitudinal body axis; copulatory pore sclerotized with straight, broad, posteriorly directed pore canal; lateral canal arms distinctly thicker in medial third. Anal somite smooth except for pair of dorsal sensilla, pair of ventral pores, and row of minute spines along posteroventral margins. Anal operculum wide, weakly crescentic, unsclerotized.

Caudal ramus (Fig. 16b, c) 3.10 times longer than wide, without ornament (length $67 \mu \mathrm{m}$ ). Lateral seta inserted at posterior third of ramus. All caudal setae finely plumed except for smooth dorsal seta in holotype. Lengths of holotype caudal setae $(\mu \mathrm{m})$ : lateral 30 , dorsal 55 , lateralmost to medialmost terminal $40,219,323,57$. Holotype with aberrant median terminal seta on right caudal ramus (shorter than outer one). Inner median terminal seta slightly bulbous just distally from breaking plane.

Antennule (Fig. 17a) of 17 segments, reaching posterior edge of second pedigerous somite (Fig. 16a). Segments (Roman numerals) with number of setae (Arabic numerals), spines and aesthetascs in parentheses: I (8), II (4), III (2), IV (6), V (1+spine), VI (2+spine), VII (2), VIII (1), IX (1), X (0), XI (1), XII (1+aesth.), XIII (1), XIV (1), XV (2), XVI (3), XVII (7+aesth.). Aesthetasc on segment XII reaching far beyond segment XIV. Segment I with transverse row of slender spinules. Hyaline membrane on segment XVI finely denticulate and only half as long as segment. Hyaline membrane of segment XVII with slightly larger denticles and situated only in distal half of segment (Fig. 17e).

Antenna (Fig. 17f) 4-segmented; basipodite with 1 long exopodal seta and 2 medial setae. Frontal surface of basipodite (Fig. 18h) with 1 cluster of 17 narrow spinules in middle and 3 minute spinules on proximal third of outer margin. Inner proximal third with 1 oblique row of tiny spinules. Caudal side of basipodite (Fig. 18g) with 2 short distal spinule groups (6 and 5 spinules) and 2 proximal spinule groups (3 and 7), parallel to outer margin. Inner margin with 3 minute spinules on proximal third. Second segment with 1 seta and third segment with 9 (8 attenuated) setae. Segment 4 with 7 distal setae, 4 of these attenuated distally.

Mandible (Fig. 18a) with normal complement of 2 long and 1 short setae. Gnathobasis surface smooth except for 1 short row of narrow spinules near biting edge.

Maxillule (Fig. 18b) without ornament on surface of palp. Armament of praecoxa, coxa and palp normal for genus, except setae of palp attenuated.

Maxilla (Fig. 18f) somewhat broader than in $M$. yutsil. Proximal endite with 2 long $(50 \mu \mathrm{m})$ plumose setae. Median endite densely set with spinules along stem (distal part broken in the 3 dissected females). Claw armed with narrow teeth from median third to distal tip. Two-segmented endopodite with 2 slender setae (Fig. 18e, f) and 3 long attenuated setae, all setae smooth.

Maxilliped (Fig. 18c, d) with 3 curved rows of slender spinules on caudal side of second segment. Frontal surface of first and second segments ornamented with groups of narrow spines. Setae attenuated, with whiplike tips except for median seta of segment 1 and distalmost seta of segment 4 .

Legs $1-4$ (Figs. 19a-d, 20a-i) with 3-segmented rami; aspect of legs 1 and 2 more robust than slender legs 3 and 4 . Terminal segments of exopodites with $2,3,3,3$ spines and 4, 4, 4, 4 setae, respectively. Spines on exopodites of leg 2 and leg 3 more robust than in $M$. yutsil, and spines of leg 1 exopodite with flagellum-like tip, at most half as long as in $M . y u t s i l$. Medial basipodite spine of leg 1 with flagellum-like tip, not reaching distal margin of second endopodal segment. Setae on leg 1 rami attenuated; naked tips, however, not as slender as in $M$. yutsil. Distal spines on third endopodal seg- 


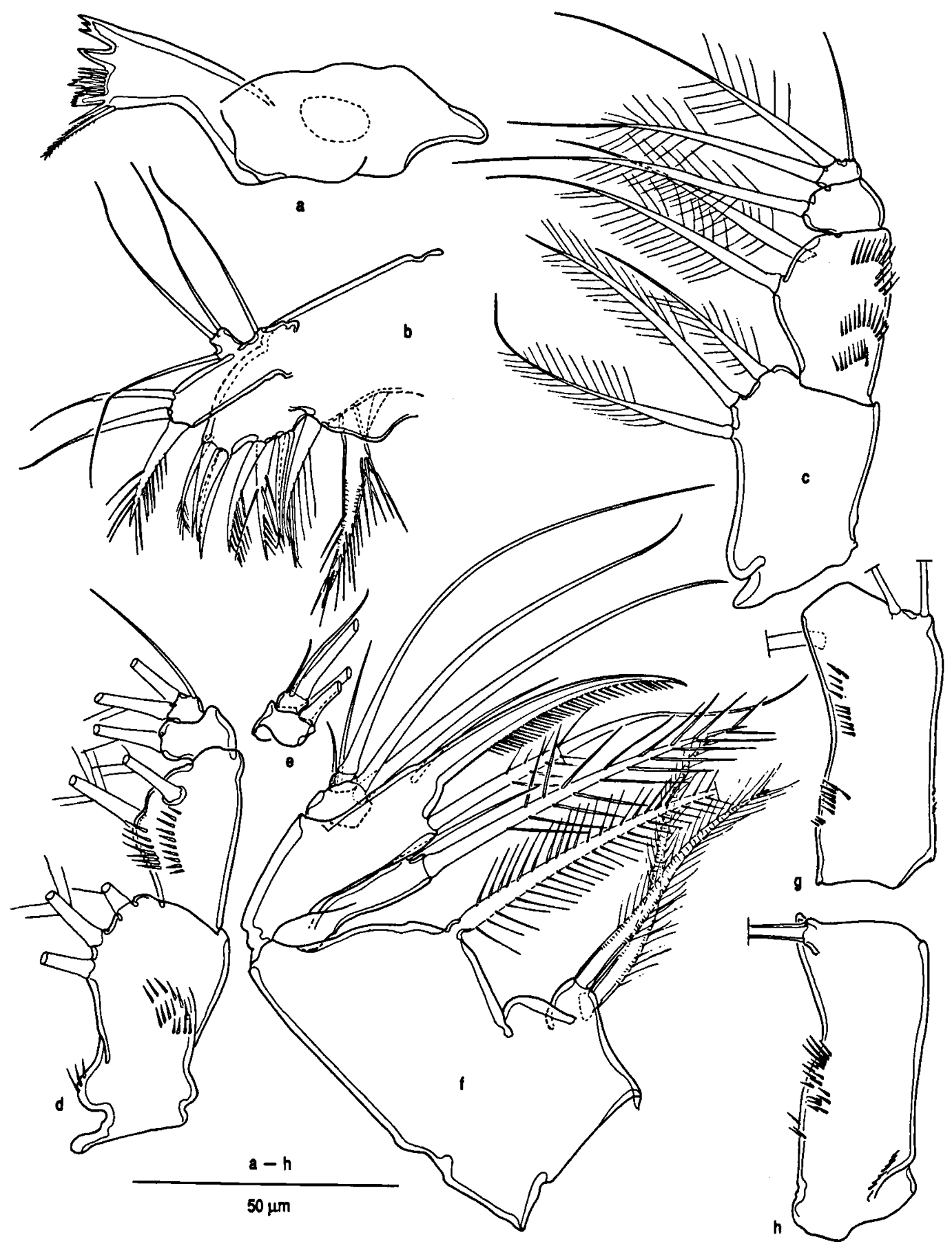

Fig. 18. Mesocyclops chaci sp. n., a-c, paratype $\&$, COP 3814; d, paratype, , COP 3812; e-h, holotype $\&$, COP 3813: a, gnathobasis of mandible; b, maxillule; c, maxilliped, caudal; $d$, maxilliped, frontal; e, maxillar endopodite; f, maxilla; $g$, antenna basipodite, caudal; h, antenna basipodite, frontal.

Fig. 19. Mesocyclops chaci sp. n., paratype 9, COP 3814: a, leg 1; b, leg 2; c, leg 3; d, leg 4 (setal ornamentation in b-d not drawn, all illustrated in frontal view). 


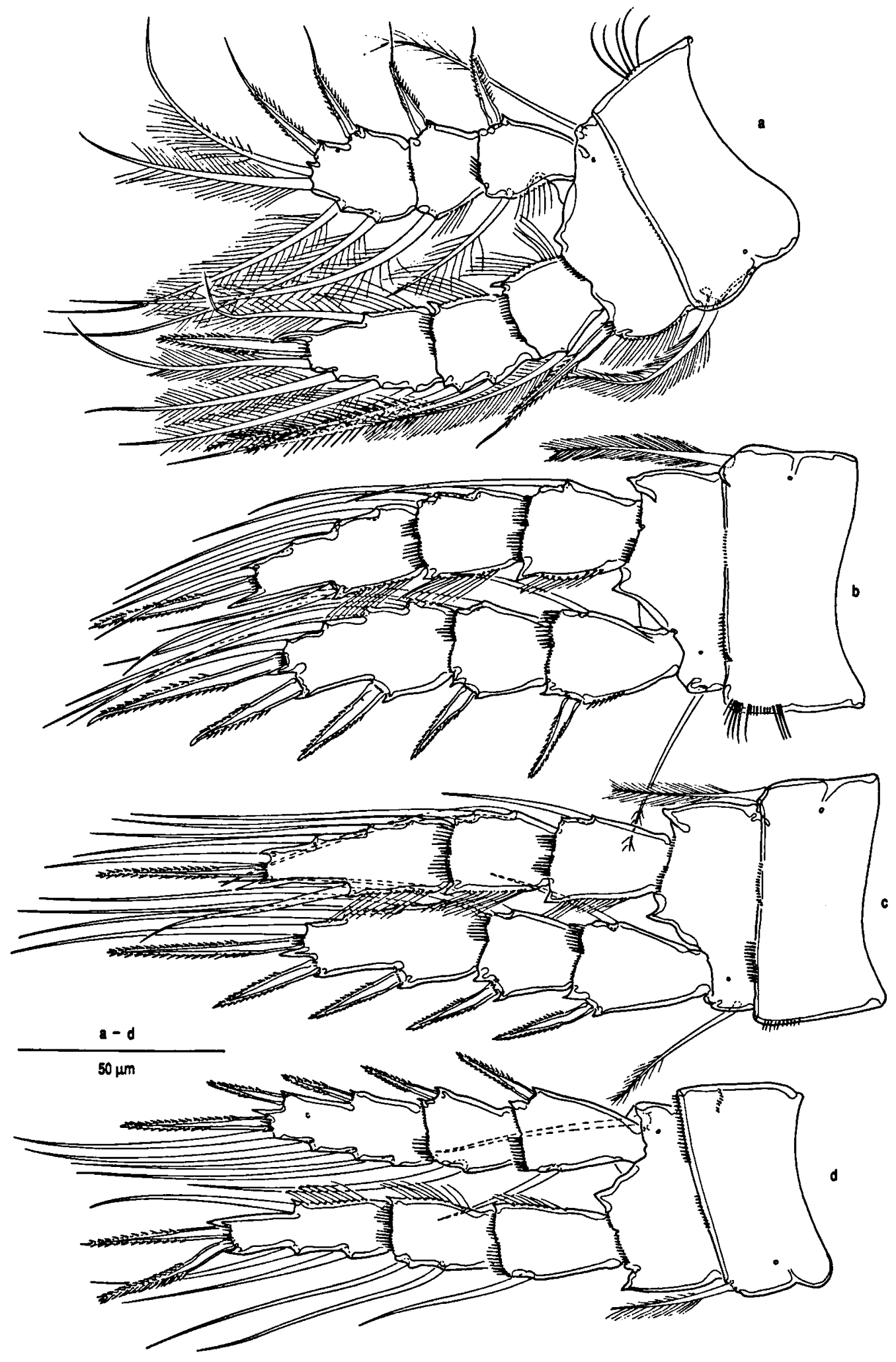




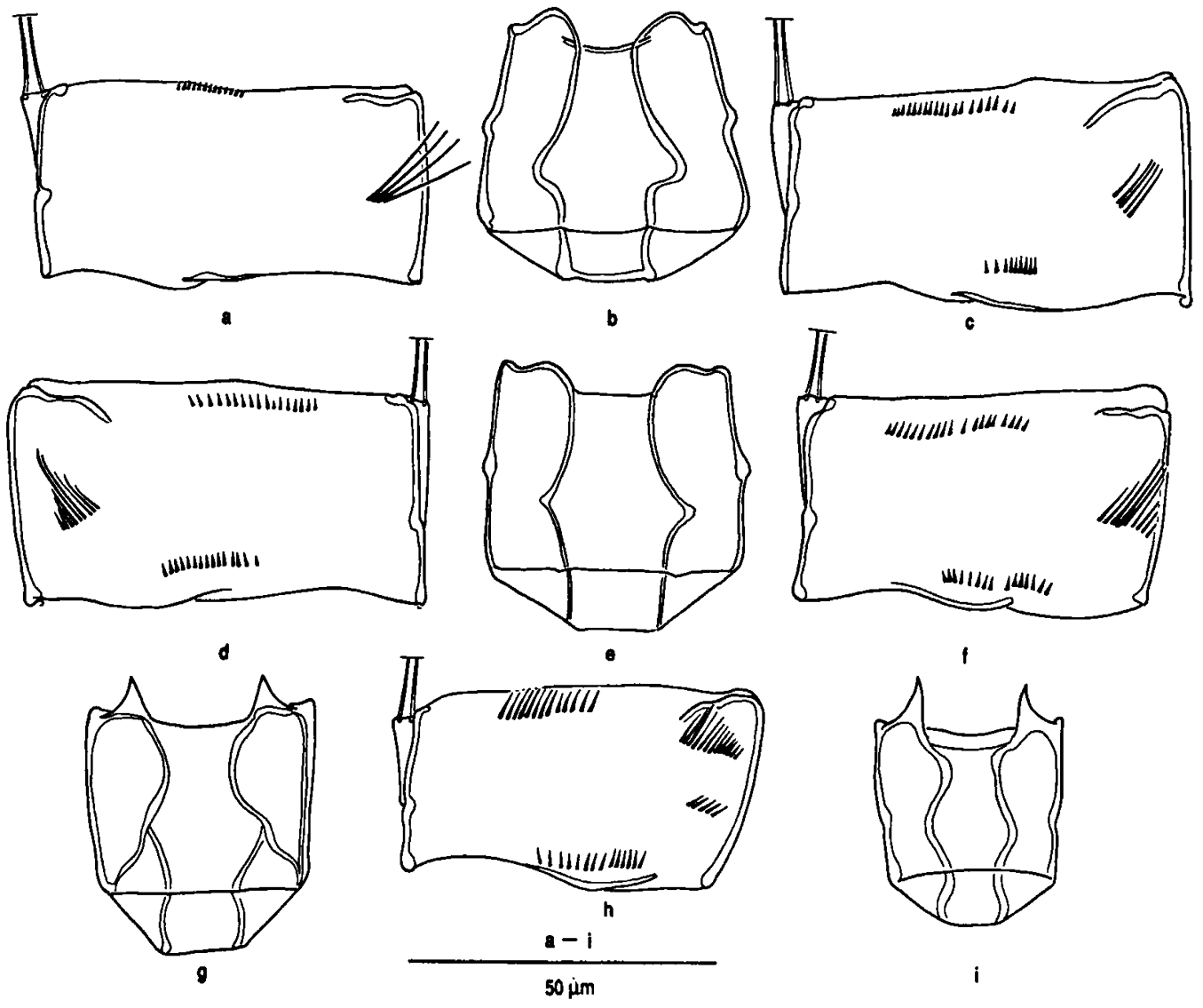

Fig. 20. Mesocyclops chaci sp. n., paratype 9 , COP 3812: a, leg 1 coxopodite; b, leg 1 coupler; c, leg 2 coxopodite; d, leg 3 coxopodite; e, leg 2 coupler; $f$, leg 3 coxopodite; $g$, leg 3 coupler; $h$, leg 4 coxopodite; $i$, leg 4 coupler (all illustrated in caudal view).

ments of leg 2 and leg 3 as long as supporting segments. Distal spines of leg 4 terminal endopodal segment about $2 / 3$ segment length, subequal in length, inner one with distinct twist in proximal third. Terminal endopodal segment of leg 4, 3 times as long as wide, with inner setae reaching not quite to ends of distal spines. Frontal surface of leg 1 coxopodite with 5 long slender spinules along outer margin and 2 short rows of minute spinules along distal margin. Caudal surface (Fig. 20a) with 4 slender spinules near outer margin and short row of minute spinules in middle of distal margin. Coxopodites of leg 2 and leg 3, frontally, with 1 row of slender spinules along outer margin and with 2 rows along distal margin. Caudal surfaces of leg 2 and leg 3 coxopodites (Fig. 20c, d, f) ornamented with oblique row of long and slender spinules near outer margin and with median distal and proximal row of short spinules. Leg 4 coxopodite (frontal) with some minute spinules perpendicular to lateral margin (not visible in COP 3812) and 2 rows along distal margin. Caudal (Fig. 20h) surface of leg 4 coxopodite as in preceding legs except for additional row of slender spinules near outer margin. Couplers of leg 1 (Fig. 20b) and leg 2 (Fig. 20e) with rounded expansions, expansions of leg 3 (Fig. 20g) and leg 4 (Fig. 20i) acute.

Leg 5 (Fig. 16d) with rather slender basal segment, distinct from somite, bearing long lateral seta. Distal segment twice as long as wide, bearing plumed terminal seta $(50 \mu \mathrm{m})$ and long serrate spiniform seta (nearly $70 \mu \mathrm{m}$ ), implanted at distal 3/4 of medial margin of segment.

Leg 6 (Fig. 16e) present as small plate with 2 short equal spines and 1 long plumed seta.

Egg sacs containing 6 to 8 eggs. 


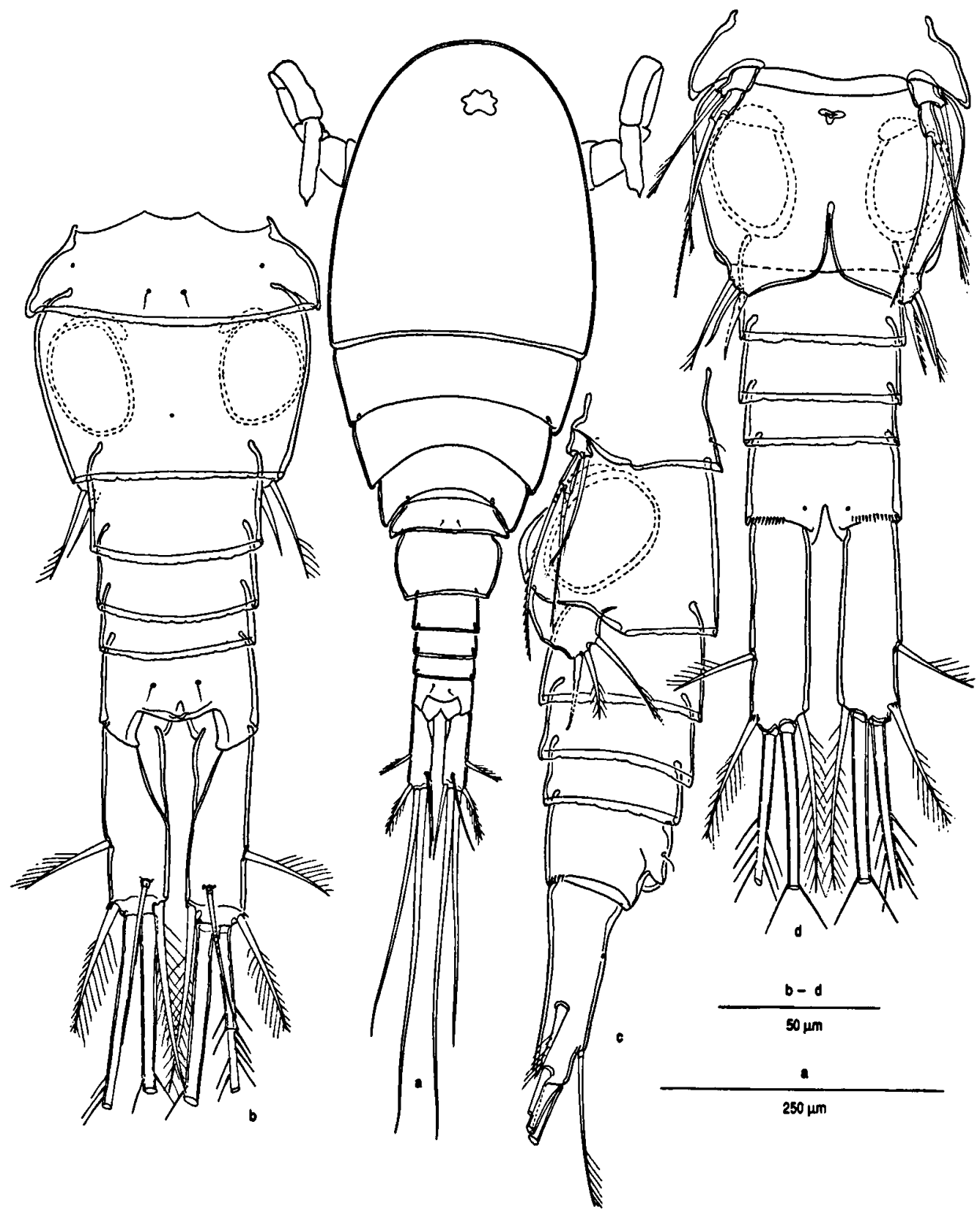

Fig. 21. Mesocyclops chaci sp. n., allotype ${ }^{\circ}$, COP 3815: a, habitus, dorsal; b, abdomen, dorsal; c, abdomen, lateral; d, abdomen, ventral.

Description of male. - Lengths of allotype, 660 $\mu \mathrm{m}$, of paratypes: 655 and $660 \mu \mathrm{m}$.

Habitus (Fig. 21a) as in female, except for normal sexual dimorphism in antennule, urosome and leg 6.

Antennule (Fig. 17b-d) geniculate, 15-segmented; first segment (Fig. 17d) with normal complement of
3 aesthetascs; segments IV, VIII and XII each with 1 aesthetasc.

Legs as in female, except for proportional lengths of medial spines of third exopodal segments of leg 3 and leg 4, specifically (L spine/ L segment) 1.33 in leg 3 (Fig. 17g) and 1.20 in leg 4 (Fig. 17h). 
Plumage of all setae and attenuation of leg 1 spines and setae as in female.

Leg 6 (Fig. 21c, d) consisting of unornamented plate bearing 1 long dorsal seta, 1 shorter median seta and 1 spiniform ventral seta.

Etymology. - The species is named after the Mayan deity Chac, the ubiquitous patron of lightning and rain.

Discussion and comparisons. - Present diagnoses of the genera Mesocyclops, Diacyclops, and Thermocyclops differ very little, sometimes rendering assignment of species problematic (Reid, 1993b). Many species of Thermocyclops and a few of Diacyclops are planktonic and slender, with attenuate appendages similar to those of $M$. yutsil. However, $M$. yutsil and $M$. chaci are here assigned to the genus Mesocyclops because of the placement of the spiniform seta of leg 5, medially rather than subterminally on the distal (exopodite) segment, as in Diacyclops and Thermocyclops. Also, no species of Thermocyclops has triangular dentiform projections on the leg 4 coupler, although several have rounded ones (Herbst, 1986). The spine patterns of the antennule basipodite are similar in these three genera, but the pattern of the two new species most resembles that of Mesocyclops (cf. Fiers \& Van de Velde, 1984; Van de Velde, 1984a, b).

The proportions of antennule segment XVII of the female have been used to discriminate between Mesocyclops and Thermocyclops. In previously known Mesocyclops species, this segment is about 3-5 times longer than broad, and in Thermocyclops it is about 2 times longer than broad (Reid, 1985; based on personal communication to J.W. Reid from J.F. Saunders III, 1984, and J.W. Reid, personal observations). In $M$. yutsil and $M$. chaci, the only known exceptions to this rule, segment XVII is short, only about 2.3 times longer than broad.

Dahms \& Fernando (1993) and Kiefer (1981) noted the lateral extension and rotation of the lateral spine of leg 2 exopodite segment 1 in some species of Mesocyclops. This is apparently a general feature of the genus (Kiefer, 1981). It is present in $M$. yutsil, $M$. longisetus var. curvatus, $M$. reidae, and $M$. ruttneri Kiefer, 1981 (J.W. Reid, personal observations), and was illustrated by Van de Velde (1984b) for several African species. However, this spine orientation is undependable for genus diagnosis, as every fixed specimen may not show it, and the more proximal lateral spines of legs 1-3 sometimes extend laterally in species of other genera, e.g. Diacyclops bernardi (cf. Reid, 1993b) and D. hispidus (cf. Reid, 1988).

Mesocyclops chaci resembles M. yutsil in the attenuated setae on the mouthparts and leg 1, the slender shape of legs 3 and 4, and the short terminal segment of the antennule. These features easily distinguish both species from other congeners. Besides details of the spinule patterns on the coxopodites of the legs and the basipodite of the antenna, $M$. chaci is easily distinguishable from $M$. yutsil by the larger body shape, the robust aspect of leg 1 , and the distinctly longer medial serrate seta of leg 5 , which in $M$. yutsil is only half as long as the distal seta.

Four other neotropical species of Mesocyclops share several key characters with $M$. yutsil and $M$. chaci, as listed by Dussart (1987): leg 1 basipodite with a spine, leg 4 coupler with two dentiform processes, seminal receptacle with nearly horizontal lateral arms, and caudal ramus relatively short (about 3 times longer than wide). These are $M$. reidae. M. intermedius Pesce, 1985, M. ellipticus Kiefer, 1936, and M. paranaensis Dussart \& Frutos, 1986. Mesocyclops ellipticus, which has been confused with $M$. reidae and may be restricted to northern South America (Petkovski, 1986), M. intermedius, known from groundwater in Bonaire, and $M$. paranaensis, a planktonic species from Brazil, Paraguay and northern Argentina, differ from both Mesocyclops species described here in having the pediger 5 with lateral spines, the caudal rami haired along the medial surface, and the medialmost terminal caudal seta more than 2.5 times longer than the lateralmost terminal caudal seta (Dussart \& Frutos, 1986; Kiefer, 1936; Pesce, 1985).

A close ancestral relationship between $M$. yutsil and $M$. chaci and $M$. reidae, a small, stout, mainly epibenthic species that is common in the Antilles and Central America into southern Mexico, is easily inferred. Mesocyclops reidae has the pediger 5 with stiff lateral spines, and the robust swimming legs that are normal in the genus. It is otherwise 
remarkably similar to $M$. yutsil in the short medialmost terminal caudal seta, the caudal ramus without hairs on the medial surface, the structure of the seminal receptacle including details of the copulatory pore and pore canal, the narrow, finely serrate antennular hyaline membrane with the membrane on segment 17 not extending proximally past the midlength seta, the simple antenna basipodite spine pattern, the three transverse rows of spines on the basis of the maxilliped, and the paired processes of the legs 1-4 couplers, which are always well developed in M. reidae and are more or less developed in different populations of $M$. yutsil and $M$. chaci (Petkovski, 1986; Reid, 1993b). Consistent differences between $M$. reidae, $M$. yutsil and $M$. chaci are the spines on pediger 5 which are always present in $M$. reidae and apparently never in $M$. yutsil and $M$. chaci, the short dorsal caudal seta of $M$. reidae, which is never longer than the lateralmost terminal caudal seta, and the fewer (about 11) and larger teeth of the labrum of $M$. reidae versus the many tiny teeth of M. yutsil and M. chaci. Additional differences are the short stout leg 1 basipodite spine of $M$. reidae, which never reaches past midlength of endopodite segment 2, and the overall gracile form of legs 3-4 of $M$. chaci and legs 1-4 of $M$. yutsil, especially the whiplike extensions of some setae and spines on the swimming legs. There are slight differences in the antennal basipodite spine patterns, in which the spine rows and lengths of the spines become gradually shorter, including an additional distal and proximal group of a few tiny spines on the caudal side in M. yutsil which in comparison with its two congeners shows the shortest spines and rows. It is clear from the foregoing that most of the morphological differences among these species are a matter of proportion, and a tendency toward reduction in body ornament and swimming leg coupler development in M. chaci and M. yutsil.

As far as known, males of $M$. reidae have the full normal complement of aesthetascs on the antennule (confirmed on two males from Chichen Itza, Yucatán, leg. G. Rodríguez-Almaraz, USNM 264523, and on four males from El Progreso, Honduras, leg. G. G. Marten, USNM 268020). The same complement of aesthetascs is displayed in the three males of M. chaci, but $M$. yutsil shows a tendency toward reduction of the aesthetasc number in the male antennule, at least in the Yuncu population.

In $M$. reidae, the antennule segment XVII is usually about 3 times longer than broad (cf. Petkovski, 1986; Reid, 1993b; Yeatman, 1977; F. Fiers and J.W. Reid, personal observations). Smith \& Fernando $(1978,1980)$ showed a slightly shorter segment for "Mesocyclops ellipticus", from Cuba; however, that population may have been $M$. reidae (Petkovski, 1986; Reid, 1990). Although local populations of this species (from wells in Quintana Roo: Mex 94-008, Mex 94-009, Mex 94-012: see additional material of $D$. chakan) show a tendency to reduce the number of segments as segments $\mathrm{V}$ and VI are partially fused, segment XVII still has the usual length/width ratio of $3: 1$ (F. Fiers, personal observations).

Mesocyclops chaci clearly takes an intermediate position in the clade $M$. reidae-chaci-yutsil. Within this species clade we see a tendency towards reduction of body size and towards a more slender aspect of the legs. Generally, Mesocyclops species have robust legs with medial spines on the third endopodal segments of the legs as long as the segment (in leg 1) but distinctly shorter in legs 2 to 4 . Even the small $M$. intermedius still shows a normal proportional spine length of 0.83 in leg 4. Mesocyclops reidae, M. chaci and M. yutsil, however, display a quite different picture, with a clear tendency to prolong the medial terminal endopodal spines, reduce body size, accentuate the attenuation of the distal parts of the setae and spines of leg 1 , and shorten the terminal antennular segment (XVII). In Table I, the proportional lengths of the medial terminal spines and body size of the three species are compared with those of $M$. leuckarti. The local Yucatecan populations of $M$. reidae have medial terminal spines equal or slightly longer than the segment (F. Fiers, personal observations). Measurements of the medial terminal spines on leg 4 of M. reidae illustrated by other authors (in most cases legs 1-3 were only partially or not at all illustrated) revealed that the foreign populations of this species have significantly shorter spines in this leg, ranging from 0.85 in Pesce (1985, as M. ellipticus) to 0.93 in Reid (1993b). Comparable proportional lengths of the leg 4 spine are found in the descriptions of M. paranaensis (Dussart \& Frutos, 1986: 
Table I. Comparison of medial terminal endopodal spine length and body size of female in some species of Mesocyclops.

Length medial terminal endopodal spine / length segment 3

\begin{tabular}{llllll} 
& $\begin{array}{l}\text { Body } \\
\text { length }(\mu \mathrm{m})\end{array}$ & Leg 1 & Leg 2 & Leg 3 & Leg 4 \\
\hline M. leuckarti $^{1}$ & $1000-1153$ & 1.00 & 0.71 & 0.86 & 0.92 \\
M. reidae & $800-1200$ & 1.00 & 1.10 & 1.10 & $0.85-1.052$ \\
M. chaci & $710-730$ & 1.18 & 1.06 & 1.08 & 1.00 \\
M. yutsil & $536-612$ & 1.52 & 1.41 & 1.32 & 1.29 \\
\hline
\end{tabular}

'After Van de Velde (1984b). ${ }^{2}$ After Petkovski (1986), Reid (1993b), and F. Fiers, personal observations.

0.83; Lowndes, 1934: 0.91), M. intermedius (Pesce, 1985: 0.86) and M. ellipticus (Kiefer, 1936: 0.94; Dussart, 1984: 1.00), three species which share several key characteristics with the species clade described here (see discussion above).

Mesocyclops reidae lives mainly in epigean habitats such as small ephemeral waters and artificial containers (Marten et al., 1994), ricefields (Reid, 1993b), a lagoon (Smith \& Fernando, 1978, 1980), and small ponds (E. Suárez-Morales, J.W. Reid \& G. Rodríguez-Almaraz, unpublished data), and also in hypogean habitats: the interstitial of a sandy riverbank (Pesce, 1985), springs (Petkovski, 1986), a cave (Yeatman, 1977, as M. ellipticus), and dug wells (Pesce, 1985; present contribution).

The collection information implies that $M$. chaci is a benthic crevicular species, while $M$. yutsil lives in large open spaces of the karst, at depths close to the surface. As such it seems that $M$. yutsil shared a crevicular living ancestor with $M$. chaci, but evolved for a planktonic existence in the Yucatán cenotes. It is as if the near ancestor of $M$. reidae, with a propensity to invade hypogean habitats, evolved for an exclusively hypogean existence in a karstic environment. When the smaller karstic cavities (crevices, interstitial etc.) became larger through solution of the limestone, an entire new environment became available for hypogean species. It has been suggested several times that ancestral copepods were epibenthic, giving rise to planktonic forms (cf. discussion by Huys \& Boxshall, 1991). The hypothesized relationship between $M$. reidae, $M$. chaci, and $M$. yutsil serves as another demonstration of this supposed sequence on the intrageneric level.

\section{General discussion}

As discussed in the former paragraphs, morphological similarities suggest close ancestral relationships between Diacyclops chakan and its local benthic congener $D$. puuc, and between Mesocyclops $y u t s i l$ and $M$. chaci and the local benthic congener $M$. reidae. The differences consist of some attenuation in appendages (carried to an extreme in $M$. yutsil) and tendencies toward reduction in body and appendage ornamentation. We infer from collection information that $D$. chakan, D. puuc, and $M$. chaci are benthic crevicular living species and that Mesocyclops yutsil inhabits large open spaces of the karst, at depths close to the surface.

With respect to their gracefully attenuate appendages, $M$. yutsil and $M$. chaci (although $M$. yutsil more than $M$. chaci) strikingly resemble another subterranean species, Kieferiella delamarei (LescherMoutoué, 1971; 1976), which is known from the saturated zone of a karst system in France. The actual microhabitat of $K$. delamarei is not known. A few specimens were taken from a spring and a groundwater seep (Lescher-Moutoué, 1971), and many were pumped from a $60 \mathrm{~m}$ well (LescherMoutoué, 1976). Several typically epigean benthic and planktonic cyclopoids of the genera Diacyclops, Eucyclops, Megacyclops, Paracyclops, and Tropocyclops occurred in the latter sample (Lescher-Moutoué, 1976). In contrast to the typical facies of most interstitial cyclopines, which have stocky wedge-shaped bodies and short reduced appendages (Reid \& Strayer, 1994), K. delamarei and both Yucatecan Mesocyclops are slender, with attenuated appendages such as are more usually found in planktonic species, although in these three 
species the degree of attenuation is extreme. Significant diagnostic features of the genus Kieferiella Lescher-Moutoué, 1976, a member of the Mesocyclops-Thermocyclops-Diacyclops group, include the unusual elongation of the swimming leg rami, setae and spines, the long setiform tips of the leg 1 exopodite spines, and the lack of aesthetascs in the antennule of the male. Mesocyclops chaci and $M$. yutsil share the former features, while $M$. yutsil additionally shows a tendency toward reduction of the number of aesthetascs in the antennule of the male, at least in one population. Because both Yucatecan Mesocyclops species do possess aesthetascs on the male antennule and the leg 5 spiniform seta inserted medially on the distal segment (rather than subterminally as in $K$. delamarei, Thermocyclops, and Diacyclops) it does not seem appropriate to assign them to the genus Kieferiella. Another, possibly genus-level distinction is that in $K$. delamarei the next lateralmost terminal caudal seta is reduced, equal or shorter than the medialmost terminal caudal seta. The leg 4 coupler of $K$. delamarei has two rounded marginal expansions but is otherwise unornamented (Lescher-Moutoué, 1971; 1976). The terminal segments of the antennule of $K$. delamarei lack a hyaline membrane (J.W. Reid, personal observation). Because of its overall similarity to the specialized $M$. yutsil, we speculate whether the principal habitat of $K$. delamarei might be in large open spaces in the karst groundwater.

The similarities between $K$. delamarei, $M$. chaci and $M$. yutsil imply some function for appendage attenuation in the hypogean environment. Most species of Mesocyclops are omnivorous, tending toward carnivory, with sturdy biting mouthparts. There is considerable variation in types of cenotes depending on light input, benthic algae, phytoplankton, current patterns, and human impact. Some cenote pools (e.g. Mayan Blue) are seasonally stratified with a layer of murky water in the upper 1-2 m overlying very clear waters. Copepods appear to be most numerous in this murky layer. In the caves, most troglobiotic species (mysids, atyid shrimp, thermosbaenaceans, etc.) are exclusively found swimming in the water column, suggesting that this is the location of their food source. Perhaps bacteria or protozoans as well as particulate organic matter may be involved in the cenote food webs. The presence of several of the usual local epigean planktonic copepods in some of the samples implies the availability of phytoplankton and/or detritus. The attenuate form of the mouthparts of both $K$. delamarei and $M$. yutsil suggests that they may feed chiefly on particulate organic matter and possibly phytoplankton in the case of the latter species. The long slender swimming legs with their delicate setae may serve to maintain the animals in position in the water with minimal expenditure of energy, in a situation where rapid avoidance of predators may be relatively unimportant. Most cenote fishes feed upon benthic fauna including copepods and seem to avoid the central (illuminated) parts of the cenotes (Navarro-Mendoza \& Valdés-Casillas, 1990). Planktonic behavior of some cenote copepods may be an adaptive strategy to avoid predators.

The attenuate tips of the leg 1 spines may have some function, possibly tactile, other than swimming. Short hairlike tips occur on swimming leg lateral spines of some cyclopines of both planktonic and epibenthic habit, e.g. Mesocyclops ruttneri (cf. Reid, 1993b), M. dussarti Van de Velde, $1984 \mathrm{~b}$, and $M$. kieferi Van de Velde, 1984b; and are well demonstrated in the local populations of $M$. reidae (F. Fiers, personal observations).

It is unusual for species of Mesocyclops to occur in hypogean and cave habitats. The only other congener known exclusively from a cave environment is $M$. cuttacuttae Dumont \& Maas, 1985 from northern Australia. Mesocyclops pilosus Kiefer, 1930 was found in a cave and small ponds on Madagascar and Aldabra (Kiefer, 1930; 1981). Each closely resembles local epigean species, i.e. is within usual parameters for the genus (Dumont \& Maas, 1985). Mesocyclops reidae lives in both epigean and hypogean environments. The common, normally epigean planktonic North and Central American M. edax (S. A. Forbes, 1891) has been found in Mammoth Cave, U.S.A. (Chappuis, 1929) and in interstitial sand of a partly dry streambed (D.L. Strayer, pers. comm. to J.W.Reid, 1994). Of course several Mesocyclops species commonly occur in semi-hypogean habitats such as shallow dug wells, where pondlike conditions apparently obtain (cf. Kiefer, 1981; Pesce, 1985; Van de Velde, 1984b). Although it is likely that 
additional collections of Mesocyclops will be made from open waters in caves, strikingly modified species such as $M$. yutsil are to be expected only in the unusual large subterranean pools developed in karst topography.

The three Mesocyclops species: $M$. reidae, $M$. chaci and $M$. yutsil are considered here as a species flock which have radiated as specialists within a highly dynamic geomorphological environment. Lacustrine species flocks are defined as monophyletic groups of three or more species and subspecies which are endemic to a particular lake, and are only known for cyclopoids in Lake Baikal (Boxshall \& Evstigneeva, 1994). Although the definition refers particularly to lakes, the karstic Yucatán plain can be considered as an immense subterranean water reservoir recharged annually with $9,800 \times 10^{6} \mathrm{~m}^{3}$ of fresh water. It has been estimated that along only the $1,100 \mathrm{~km}$ northern coastline, $9,450 \times 10^{6} \mathrm{~m}^{3}$ of fresh groundwater is discharged annually into the sea (Back, 1985). In other words, it seems as if the Yucatán Peninsula is drifting on a gigantic water lake extending throughout its subterranean karstic topography.

Large subterranean karstic cavities are only a transitional geomorphological phenomenon. When karstification proceeds and the limestones erode further, the typical cenote (from the Mayan word Tz'onot or D'zonot, meaning well) is formed when the roof of the cavern collapses, forming a sinkhole. At that moment the entire physical and chemical situation of the water body is drastically altered as it becomes exposed to epigean influences. The entire fauna and flora changes rapidly, especially under the tropical conditions of these waters. Specialists such as $M$. chaci and $M$. yutsil can no longer succeed in this particular place and are replaced by primarily epigean forms such as $M$. longisetus curvatus.

Geological evidence indicates that the northern plain (mainly of Mio-Pliocene age with a central nucleus of Eocene age, and two small lenses of Oligocene age, cf. Lopez-Ramos, 1975; Weidie, 1985) was submerged by Pleistocene seas during the Yarmouth interglacial (170-220 $\times 10^{3}$ Y. B.P.). At that time seas reached the highest level during the Pleistocene, about $30 \mathrm{~m}$ above the present (Back, 1985; Haq \& Van Eysinga, 1987). At that time the shore- line extended from Campeche to Maxcanu in the west; along the Sierrita de Ticul to Peto in the northwest; from Peto to beyond Chichen Itza and Valladolid in the northeast; and roughly $100 \mathrm{~km}$ inland parallel with the present Caribbean coastline from east of Valladolid to Chetumal in the south. Thus, in contrast to the central and southeastern cenotes (those in the region above $30 \mathrm{~m}$, including inland from Chetumal) where karstification continued, the karst processes were altered in the northern and eastern karstic plain. The freshwater hypogean fauna within this area disappeared and was replaced by marine elements (e.g. thermosbaenaceans).

After the sea retreated, percolating fresh water (precipitation up to $1500 \mathrm{~mm} / \mathrm{yr}$ and subterranean water flow) refilled the old karst cavities and karstification processes were reactivated. However, up to the present time, saline waters still form the deeper strata of the water and act as an environmental barrier to subterranean dispersion. In this situation, populations could and still can become rapidly and efficiently separated from each other by fluctuations of the halocline, resulting in drastic reduction of genetic exchange. This geological history and suggested scenario explain the fact that populations of closely related species (such as $M$. chaci and $M$. yutsil) can be encountered in geographically close localities (Cheuman is about 2 $\mathrm{km}$ from Noc Ac).

\section{Acknowledgements}

We thank Dr. Harry C. Yeatman for helpful comments on early figures of Mesocyclops yutsil. Prof. Silvina Menu-Marque's gift of specimens of Diacyclops michaelseni, Prof. Gabino Rodriguez-Almaraz' and Dr. Gerald G. Marten's gifts of specimens of Mesocyclops reidae, and Dr. Françoise LescherMoutoue's gift of specimens of Kieferiella delamarei to the United States National Museum of Natural History (Smithsonian Institution) permitted confirmation of important comparative characters. We are indebted to Dr. Frank Moravec, visiting professor in the Parasitology Section of CINVESTAVIPN (Centro de Investigación y Estudios Avanzados del Instituto Politécnico Nacional), Mérida, for collection and donation of several samples, permitting the discovery of Mesocyclops chaci. The Department of Invertebrate Zoology, United States National Museum of Natural History provided research facilities to J.W. Reid. T.M. Iliffe's collections were supported by National Science Foundation grants BSR-8215672 and BSR- 
8417494, the Texas A\&M University at Galveston Research Enhancement Program, and the Texas Institute of Oceanography. James Coke, Michael Madden, John Pohlman, Brett Dodson, Dr. John Markham, Dr. Virginia Urbieta, Dr. Elva Escobar, Dinah Drago, and Juan José Fucat assisted T.M. Iliffe with cave diving collections. Logistical assistance was provided by the Centro de Investigaciones de Quintana Roo (CIQRO) in Chetumal, the Universidad Autónoma de Yucatán (UADY) in Mérida, and the Universidad Nacional Autónoma de México (UNAM) Marine Laboratory in Puerto Morelos, Quintana Roo. F. Fiers was offered the opportunity to make collections in Yucatan by the researchers of the Parasitology Section at CINVESTAV-IPN during his stays at the Mexican Institute in the framework of the European Community granted marine pollution project in the Gulf of Campeche. F. Fiers honors also the friendship and field assistance of the CINVESTAV-IPN researchers, Joaquin Vargas, Miguel Herrera, Victor Ceja, and not least Thomas Sholtze, who was badly attacked by Africanized bees during the November 1993 field trip. We all felt his pain.

\section{References}

Back, W., 1985. Hydrogeology of the Yucatan. In: W.C. Ward, A.E. Weidie \& W. Back (eds.), 1985. Geology and hydrogeology of the Yucatan and the Quaternary geology of northeastem Yucatan Peninsula: 99-124 (NOGS Publications, University of New Orleans).

Borutzky, E.V. \& M.E. Vinogradov, 1957. Occurrence of Cyclopidae (Acanthocyclops mirnyi, sp. n.) on the Antarctic continent. Zool. Zh., 36(2): 199-203 (In Russian; abstract in English).

Boxshall, G.A. \& T.D. Evstigneeva, 1994. The evolution of species flocks of copepods in Lake Baikal: a preliminary analysis. In: Speciation in ancient lakes. Arch. Hydrobiol. Beih. Ergebn. Limnol., 44: 235-246.

Chappuis, P.A., 1929. Copépodes cavernicoles de l'Amérique du Nord (Note préliminaire). Bull. Soc. Sti. Cluj, 4(2): 51-57.

Claus, C., 1857. Das Genus Cyclops und seine einheimischen Arten: 1-40, Taf. I-III (Inaugural-Dissertation, Marburg).

Dahms, H.-U. \& C.H. Fernando, 1993. Redescription of Mesocyclops leuckarti (Copepoda, Cyclopoida), including a study of its naupliar development. Int. Revue ges. Hydrobiol., 78(4): 589-609.

Dumont, H.J. \& S. Maas, 1985. Mesocyclops cuttacuttae sp. n. from a cave in northern Australia (Crustacea: Copepoda, Cyclopoida). Beagle, 1(13): 115-122.

Dussart, B.H., 1984. Some Crustacea Copepoda from Venezuela. Hydrobiologia, 113: 25-67.

Dussart, B.H., 1987. Sur quelques Mesocyclops (Crustacea, Copepoda) d'Amérique du Sud. Amazoniana, 10(2): 149161.

Dussart, B.H. \& D. Defaye, 1985. Répertoire mondial des Copépodes Cyclopoïdes: 1-236 (Éditions du C.N.R.S., Bordeaux).
Dussart, B.H. \& S.M. Frutos, 1986. Sur quelques Copépodes d'Argentine. Revue Hydrobiol. trop., 18(4)"1985": 305314.

Fiers, F. \& I. Van de Velde, 1984. Morphology of the antenna and its importance in the systematics of the Cyclopidae. Crustaceana, Suppl. 7(2): 182-199.

Forbes, S.A., 1891. On some Lake Superior Entomostraca. Ann. Rep. U.S. Commnr. Fish Fisheries, 1887: 701-718, Pls. I-IV.

Haq, B.U. \& F.W.B. Van Eysinga, 1987. Geological time table (4th ed.). (Elsevier Science Publishers B.V., Amsterdam).

Herbst, H.-V., 1986. Beschreibung des Thermocyclops hastatus antillensis n. ssp. mit einem Bestimmungsschlüssel für die Gattung Thermocyclops Kiefer, 1927. Bijdr. Dierk., 56(1): 165-180.

Huys, R. \& G.A. Boxshall, 1991. Copepod evolution: 1-468 (Ray Society, London).

Kiefer, F., 1930. Zur Kenntnis der freilebenden Copepoden Madagaskars. Zool. Anz., 87(1/2): 42-46.

Kiefer, F., 1936. Brasilianische Ruderfusskrebse (Crustacea Copepoda) gesammelt von Herrn Dr. Otto Schubart. V. Mitteilung. Zool. Anz., 116(1/2): 31-35.

Kiefer, F., 1981. Beitrag zur Kenntnis von Morphologie, Taxonomie und geographischer Verbreitung von Mesocyclops leuckarti auctorum. Arch. Hydrobiol., Suppl. 62 (Monogr. Beitr.), 1: 148-190.

Lescher-Moutoué, F., 1971. Les cyclopides de la zone noyée d'un karst. II. Mesocyclops (Thermocyclops) delamarei sp. n. Annls. Spéléol., 26: 473-479.

Lescher-Moutoué, F., 1976. Les cyclopides de la zone noyée d'un karst, III. Création du genre Kieferiella à la suite de nouvelles observations sur l'espèce delamarei (Crustacé, Copépode). Annls. Spéléol., 31: 91-98.

Lindberg, K., 1949. Contributions à l'étude des Cyclopides (Crustacés Copépodes). K. Fysiogr. Sällsk. Lund Förh., 19: 98-121.

Lopez-Ramos, E., 1975. Geological summary of the Yucatan Peninsula. In: A.E.M. Nairn \& F.G. Stehli (eds), The ocean basins and margins, 3. The Gulf of Mexico and the Caribbean: 257-282 (Plenum Press, New York, London).

Lowndes, A.G., 1934. Results of an expedition to Brazil and Paraguay in 1926-27. Copepoda. J. Linn. Soc. Lond., (Zool.) 39: 83-131.

Marten, G. G., G. Borjas, M. Cush, E. Fernandez \& J.W. Reid, 1994. Control of larval Aedes aegypti (Diptera: Culicidae) by cyclopoid copepods in peridomestic breeding containers. J. med. Entomol., 31(1): 36-44.

Menu-Marque, S., 1991. Los copépodos del genero Acanthocyclops de Tierra del Fuego. Biol. Acuática, 15: 142-143.

Morton, D. W., 1985. Revision of the Australian Cyclopidae (Copepoda: Cyclopoida), I. Acanthocyclops Kiefer, Diacyclops Kiefer and Australocyclops, gen. nov. Austr. J. mar. freshw. Res., 36: 615-634.

Mrázek, A., 1901. Süsswassercopepoden. Ergebnisse der Hamburger Magalhänischen Sammelreise, 2: 1-29 (Naturhistorisches Museum, Hamburg). 
Navarro-Mendoza, M. \& C. Valdés-Casillas, 1990. Peces cavernícolas de la Peninsula de Yucatán en peligro de extinción, con nuevos registros para Quintana Roo. In: J.L. Camarillo \& F. Rivera (compilers), Áreas naturales protegidas en México y especies en extinción: 218-240 (E.N.E.P. Iztacala, U.N.A.M., Mexico).

Pearse, A.S. \& C.B. Wilson, 1938. Copepoda from Yucatan caves. Publs. Carnegie Instn., 491: 153-154.

Pesce, G. L., 1985. Cyclopids (Crustacea, Copepoda) from West Indian groundwater habitats. Bijdr. Dierk., 55(2): 295-323.

Petkovski, T.K., 1986. Zur Taxonomie des Genus Mesocyclops G. O. Sars 1914 (Crustacea, Copepoda Cyclopoida) in der Neotropis. Acta Mus. maced. Sci. nat., 18(3/149): 47-79.

Reid, J.W., 1985. Chave de identificação e lista de referências bibliográficas para as espécies continentais sulamericanas de vida livre da ordem Cyclopoida (Crustacea, Copepoda). Bolm. Zool., Univ. São Paulo, 9: 17-143.

Reid, J.W., 1988. Cyclopoid and harpacticoid copepods (Crustacea) from Mexico, Guatemala, and Colombia. Trans. Am. microsc. Soc., 107: 190-202.

Reid, J.W., 1990. Continental and coastal free-living Copepoda (Crustacea) of Mexico, Central America and the Caribbean Region. In: D. Navarro L. \& J.G. Robinson (eds.), Diversidad biologica en la Reserva de la Biosfera de Sian Ka'an, Quintana Roo, México: 175-213 (Centro de Investigaciones de Quintana Roo (CIQRO) \& Program of Studies in Tropical Conservation, University of Florida; Chetumal, Quintana Roo).

Reid, J.W., 1993a. Diacyclops virginianus, a new species of Cyclopoida (Crustacea: Copepoda) from Goose Creek, Virginia. Maryland Naturalist, 37: 36-45.

Reid, J.W., 1993b. New records and redescriptions of American species of Mesocyclops and of Diacyclops bernardi (Petkovski, 1986) (Copepoda: Cyclopoida). Bijdr. Dierk., 63(3): 173-191.

Reid, J.W. \& D.L. Strayer, 1994. Diacyclops dimorphus sp. n. (Crustacea: Copepoda: Cyclopoida) from Florida, U.S.A., with comments on morphological characters of interstitial cyclopine cyclopoids. J. North Am. benthol. Soc., 13: 250-265.
Rocha, C.E.F. da, 1991. A new species of Halicyclops (Copepoda, Cyclopidae) from California, and a revision of some Halicyclops material in the collections of the US Museum of Natural History. Hydrobiologia, 226: 29-37.

Sars, G.O., 1863. Oversigt af de indenlandske Ferskvandscopepoder. Forh. Videnskabs-Selsk. Christiana, 1862: 212262.

Shen, C.-j. \& T.-h. Sung, 1963. Notes on Copepoda collected from Shigatze and Gyangtse regions in Tibet, China. Acta zool. sin., 15(1): 79-97 (in Chinese; abstract in English).

Smith, K. \& C.H. Fernando, 1978. The freshwater calanoid and cyclopoid copepod Crustacea of Cuba. Can. J. Zool., 56(9): 2015-2023.

Smith, K.E. \& C.H. Fernando, 1980. Guía para los Copépodos (Calanoida y Cyclopoida) de Cuba: 1-28 (Academia de Ciencias de Cuba, Havana).

Suárez-Morales, E., J.W. Reid, T.M. Iliffe \& F. Fiers, 1996. Catálogo de los Copépodos (Crustacea) continentales de la Península de Yucatán, México: 1-296 (ECOSUR/ CONABIO, Mexico).

Velde, I. Van de, 1984a. Introduction of new diagnostic characters in Mesocyclops, with African species as an example. Crustaceana, Suppl. 7, Stud. Copepoda, 2: 404-419.

Velde, I. Van de, 1984b. Revision of the African species of the genus Mesocyclops Sars 1914 (Copepoda: Cyclopidae). Hydrobiologia, 109: 3-66.

Weidie, A.E., 1985. Geology of the Yucatan Platform. In: W.C. Ward, A.E. Weidie \& W. Back (eds.), Geology and hydrogeology of the Yucatan and the Quaternary geology of northeastern Yucatan Peninsula: 1-19 (NOGS Publications, University of New Orleans).

Wilson, C.B., 1936. Copepods from the cenotes and caves of the Yucatan Peninsula, with notes on cladocerans. Publs. Carnegie Instn., 457: 77-88.

Yeatman, H.C., 1943. Rare cyclopoid copepods from wells in North Carolina. J. Elisha Mitchell scient. Soc., 59: 27-36.

Yeatman, H.C., 1977. Mesocyclops ellipticus Kiefer from a Mexican cave. In: J.R. Reddell (ed.), Studies on the caves and cave fauna of the Yucatan Peninsula. Bull. Assoc. Mex. Cave Stud., 6: 5-7.

First draft received: 4 December 1995 